\title{
Historical and future contributions of inland waters to the Congo Basin carbon balance
}

\author{
Adam Hastie ${ }^{1,2}$, Ronny Lauerwald ${ }^{2,3,4}$, Philippe Ciais ${ }^{3}$, Fabrice Papa ${ }^{5,6}$, and Pierre Regnier ${ }^{2}$ \\ ${ }^{1}$ School of GeoSciences, University of Edinburgh, EH9 3FF, Edinburgh, Scotland, UK \\ ${ }^{2}$ Biogeochemistry and Earth System Modelling, Department of Geoscience, Environment and Society, \\ Université Libre de Bruxelles, Bruxelles, 1050, Belgium \\ ${ }^{3}$ Laboratoire des Sciences du Climat et de l'Environnement (LSCE), \\ CEA CNRS UVSQ, Gif-sur-Yvette, 91191, France \\ ${ }^{4}$ Université Paris-Saclay, INRAE, AgroParisTech, UMR ECOSYS, Thiverval-Grignon, 78850, France \\ ${ }^{5}$ Laboratoire d'Etudes en Géophysique et Océanographie Spatiales, Centre National de la Recherche \\ Scientifique - Institut de recherche pour le développement - Université Toulouse Paul Sabatier - \\ Centre national d'études spatiales, Toulouse, 31400, France \\ ${ }^{6} \mathrm{UnB}$, Universidade de Brasília, Institute of Geosciences, Campus Universitario Darcy Ribeiro, \\ 70910-900 Brasilia (DF), Brazil
}

Correspondence: Adam Hastie (adam.hastie@ed.ac.uk)

Received: 4 February 2020 - Discussion started: 11 March 2020

Revised: 29 October 2020 - Accepted: 16 November 2020 - Published: 7 January 2021

\begin{abstract}
As the second largest area of contiguous tropical rainforest and second largest river basin in the world, the Congo Basin has a significant role to play in the global carbon (C) cycle. For the present day, it has been shown that a significant proportion of global terrestrial net primary productivity (NPP) is transferred laterally to the land-ocean aquatic continuum (LOAC) as dissolved $\mathrm{CO}_{2}$, dissolved organic carbon (DOC), and particulate organic carbon (POC). Whilst the importance of LOAC fluxes in the Congo Basin has been demonstrated for the present day, it is not known to what extent these fluxes have been perturbed historically, how they are likely to change under future climate change and land use scenarios, and in turn what impact these changes might have on the overall $\mathrm{C}$ cycle of the basin. Here we apply the ORCHILEAK model to the Congo Basin and estimate that $4 \%$ of terrestrial NPP $\left(\mathrm{NPP}=5800 \pm 166 \mathrm{Tg} \mathrm{C} \mathrm{yr}^{-1}\right)$ is currently exported from soils and vegetation to inland waters. Further, our results suggest that aquatic $\mathrm{C}$ fluxes may have undergone considerable perturbation since 1861 to the present day, with aquatic $\mathrm{CO}_{2}$ evasion and $\mathrm{C}$ export to the coast increasing by $26 \%$ (186 \pm 41 to $235 \pm 54 \mathrm{Tg} \mathrm{C} \mathrm{yr}^{-1}$ ) and $25 \%$ (12 \pm 3 to $15 \pm 4 \mathrm{Tg} \mathrm{C} \mathrm{yr}^{-1}$ ), respectively, largely because of rising atmospheric $\mathrm{CO}_{2}$ concentrations. Moreover, under climate scenario RCP6.0 we predict that this perturbation could continue; over the full simulation period (1861-2099), we estimate that aquatic $\mathrm{CO}_{2}$ evasion and $\mathrm{C}$ export to the coast could increase by $79 \%$ and $67 \%$, respectively. Finally, we show that the proportion of terrestrial NPP lost to the LOAC could increase from approximately $3 \%$ to $5 \%$ from 1861-2099 as a result of increasing atmospheric $\mathrm{CO}_{2}$ concentrations and climate change. However, our future projections of the Congo Basin C fluxes in particular need to be interpreted with some caution due to model limitations. We discuss these limitations, including the wider challenges associated with applying the current generation of land surface models which ignore nutrient dynamics to make future projections of the tropical $\mathrm{C}$ cycle, along with potential next steps.
\end{abstract}




\section{Introduction}

As the world's second largest area of contiguous tropical rainforest and second largest river, the Congo Basin has a significant role to play in the global carbon (C) cycle. Current estimates of its $\mathrm{C}$ stocks and fluxes are limited by a paucity of field data and therefore have substantial uncertainties, both quantified and unquantified (Williams et al., 2007; Lewis et al., 2009; Dargie et al., 2017). Nevertheless, it has been estimated that there is approximately $50 \mathrm{Pg} \mathrm{C}$ stored in its aboveground biomass (Verhegghen et al., 2012) and up to $100 \mathrm{Pg} \mathrm{C}$ contained within its soils (Williams et al., 2007). Moreover, a recent study estimated that around $30(6.3-46.8) \mathrm{PgC}$ is stored in the peats of the Congo alone (Dargie at al., 2017). Field data suggest that storage in tree biomass increased by 0.34 (0.15-0.43) $\mathrm{Pg} \mathrm{C} \mathrm{yr}^{-1}$ in intact African tropical forests between 1968 and 2007 (Lewis et al., 2009) due in large part to a combination of increasing atmospheric $\mathrm{CO}_{2}$ concentrations and climate change (Ciais et al., 2009; Pan et al., 2015), while satellite data indicate that terrestrial net primary productivity (NPP) has increased by an average of $10 \mathrm{~g} \mathrm{C} \mathrm{m}^{-2} \mathrm{yr}^{-1}$ per year between 2001 and 2013 in tropical Africa (Yin et al., 2017).

At the same time, forest degradation, clearing for rotational agriculture, and logging are causing $\mathrm{C}$ losses to the atmosphere (Zhuravleva et al., 2013; Tyukavina et al., 2018), while droughts have reduced vegetation greenness and water storage over the last decade (Zhou et al., 2014). A recent estimate of above-ground $\mathrm{C}$ stocks in tropical African forests, mainly in the Congo, indicates a minor net $\mathrm{C}$ loss from 2010 to 2017 (Fan et al., 2019). Moreover, recent field data suggest that the above-ground $\mathrm{C}$ sink in tropical Africa was relatively stable from 1985 to 2015 (Hubau et al., 2020).

There are large uncertainties associated with projecting future trends in the Congo Basin terrestrial $\mathrm{C}$ cycle, firstly related to predicting which trajectories of future $\mathrm{CO}_{2}$ levels and land use changes will occur and secondly to our ability to fully understand and simulate these changes and in turn their impacts. Future model projections for the 21 st century agree that temperature will significantly increase under both low and high emission scenarios (Haensler et al., 2013), while precipitation is only projected to substantially increase under high emission scenarios, with the basin mean remaining more or less unchanged under low emission scenarios (Haensler et al., 2013). Uncertainties in future land use change projections for Africa are among the highest for any continent (Hurtt et al., 2011).

For the present day at the global scale, it has been estimated that between 1 and $5 \mathrm{PgC}^{-1}$ is transferred laterally to the land-ocean aquatic continuum (LOAC) as dissolved $\mathrm{CO}_{2}$, dissolved organic carbon (DOC), and particulate organic carbon (POC) (Cole at al., 2007; Tranvik et al., 2009; Regnier et al., 2013; Drake et al., 2018; Ciais et al., 2020). This $C$ can subsequently be evaded back to the atmosphere as $\mathrm{CO}_{2}$, undergo sedimentation in wetlands and inland waters, or be transported to estuaries or the coast. The tropical region is a hotspot area for inland water $\mathrm{C}$ cycling (Richey et al., 2002; Melack et al., 2004; Abril et al., 2014; Borges et al., 2015a; Lauerwald et al., 2015) due to high terrestrial NPP and precipitation, and a recent study used an upscaling approach based on observations to estimate present-day $\mathrm{CO}_{2}$ evasion from the rivers of the Congo Basin at $251 \pm 46 \mathrm{Tg} \mathrm{C} \mathrm{yr}^{-1}$ and the lateral C (TOC + DIC) export to the coast at $15.5(13-18) \mathrm{Tg} \mathrm{C} \mathrm{yr}^{-1}$ (Borges at al., 2015a, 2019). To put this into context, the estimate of aquatic $\mathrm{CO}_{2}$ evasion represents $39 \%$ of the global value estimated by Lauerwald et al. $\left(2015,650 \mathrm{Tg} \mathrm{Cyr}^{-1}\right)$ or $14 \%$ of the global estimate of Raymond et al. $\left(2013,1800 \mathrm{Tg} \mathrm{C} \mathrm{yr}^{-1}\right)$. Note that while Lauerwald et al. (2015) and Raymond et al. (2013) relied largely on the same database of partial pressure of $\mathrm{CO}_{2}\left(p \mathrm{CO}_{2}\right)$ measurements (GloRiCh; Hartmann et al., 2014) as the basis for their estimates, they took different, albeit both empirically led, approaches. Moreover, both approaches were limited by a relative paucity of data from the tropics, which also explains the high degree of uncertainty associated with our understanding of global riverine $\mathrm{CO}_{2}$ evasion.

Whilst the importance of LOAC fluxes in the Congo Basin has been demonstrated for the present day, it is not known to what extent these fluxes have been perturbed historically, how they are likely to change under future climate change and land use scenarios, and in turn what impact these changes might have on the overall $\mathrm{C}$ balance of the Congo. In light of these knowledge gaps, we address the following research questions.

- What is the relative contribution of LOAC fluxes $\left(\mathrm{CO}_{2}\right.$ evasion and $\mathrm{C}$ export to the coast) to the present-day $\mathrm{C}$ balance of the basin?

- To what extent have LOAC fluxes changed from 1861 to the present day, and what are the primary drivers of this change?

- How will these fluxes change under future climate and land use change scenarios (RCP6.0, which represents the "no mitigation" scenario), and what are the limitations associated with these future projections?

Understanding and quantifying these long-term changes requires a complex and integrated mass-conservation modelling approach. The ORCHILEAK model (Lauerwald et al., 2017), a new version of the land surface model ORCHIDEE (Krinner et al., 2005), is capable of simulating observed terrestrial and aquatic $\mathrm{C}$ fluxes in a consistent manner for the present day in the Amazon (Lauerwald et al., 2017) and Lena (Bowring et al., 2019, 2020) basins, albeit with limitations including a lack of explicit representation of POC fluxes and in-stream autotrophic production (see Lauerwald et al., 2017; Bowring et al., 2019, 2020; and Hastie et al., 2019, for further discussion). Moreover, it was recently demonstrated that 
this model could recreate observed seasonal and interannual variation in Amazon Basin aquatic and terrestrial $\mathrm{C}$ fluxes (Hastie et al., 2019).

In order to accurately simulate aquatic $\mathrm{C}$ fluxes, it is crucial to provide a realistic representation of the hydrological dynamics of the Congo River, including its wetlands. Here, we develop new wetland forcing files for the ORCHILEAK model from the high-resolution dataset of Gumbricht et al. (2017) and apply the model to the Congo Basin. After validating the model against observations of discharge, flooded area, DOC concentrations, and $p \mathrm{CO}_{2}$ for the present day, we then use the model to understand and quantify the long-term (1861-2099) temporal trends in both the terrestrial and aquatic $\mathrm{C}$ fluxes of the Congo Basin.

\section{Methods}

ORCHILEAK (Lauerwald et al., 2017) is a branch of the ORCHIDEE land surface model (LSM), building on past model developments such as ORCHIDEE-SOM (Camino-Serrano et al., 2018), and represents one of the first LSM-based approaches which fully integrates the aquatic $\mathrm{C}$ cycle within the terrestrial domain. ORCHILEAK simulates DOC production in the canopy and soils, the leaching of dissolved $\mathrm{CO}_{2}$ and $\mathrm{DOC}$ to the river from the soil, the mineralization of DOC, and in turn the evasion of $\mathrm{CO}_{2}$ to the atmosphere from the water surface. Moreover, it represents the transfer of $\mathrm{C}$ between litter, soils, and water within floodplains and swamps (see Sect. 2.2). Once within the river-routing scheme, ORCHILEAK assumes that the lateral transfer of $\mathrm{CO}_{2}$ and DOC is proportional to the volume of water. DOC is divided into a refractory and labile pool within the river, with half-lives of 80 and $2 \mathrm{~d}$, respectively. The refractory pool corresponds to the combined slow and passive DOC pools of the soil $\mathrm{C}$ scheme, and the labile pool corresponds to the active soil pool (see Sect. 2.4.1). The concentration of dissolved $\mathrm{CO}_{2}$ and the temperature-dependent solubility of $\mathrm{CO}_{2}$ are used to calculate $p \mathrm{CO}_{2}$ in the water column. In turn, $\mathrm{CO}_{2}$ evasion is calculated based on $p \mathrm{CO}_{2}$, along with a diurnally variable water surface area and a gas exchange velocity. Fixed gas exchange velocities of 3.5 and $0.65 \mathrm{~m} \mathrm{~d}^{-1}$, respectively, are used for rivers (including open floodplains) and forested floodplains.

In this study, as in previous studies (Lauerwald et al., 2017; Hastie et al., 2019; Bowring et al., 2019, 2020), we run the model at a spatial resolution of $1^{\circ}$ and use the default time step of $30 \mathrm{~min}$ for all vertical transfers of water, energy, and $\mathrm{C}$ between vegetation, soil, and the atmosphere, as well as the daily time step for the lateral routing of water. Until now, in the tropics, ORCHILEAK has been parameterized and calibrated only for the Amazon River Basin (Lauerwald et al., 2017; Hastie et al., 2019). To adapt and apply ORCHILEAK to the specific characteristics of the Congo River Basin (Sect. 2.1), we had to establish new forcing files rep-

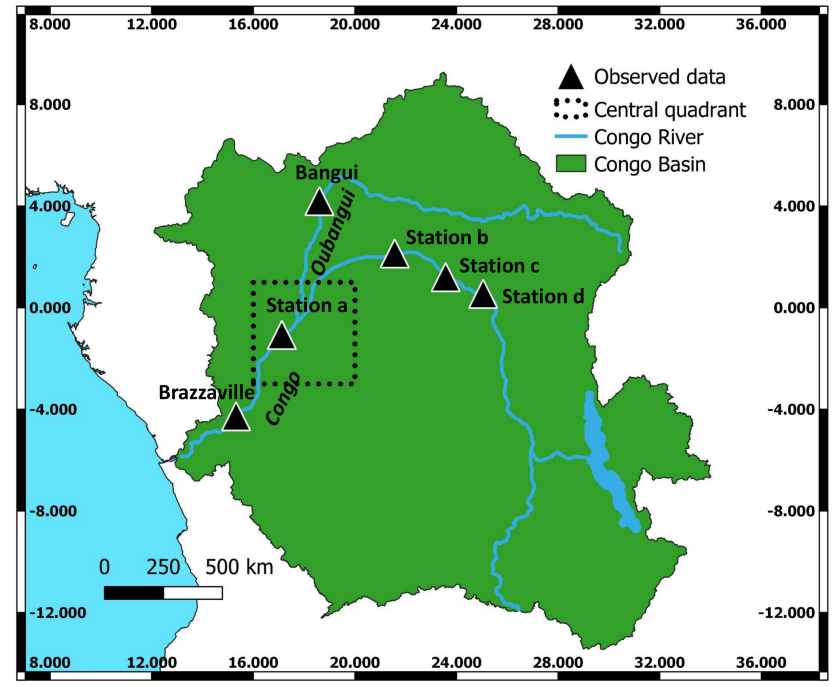

Figure 1. Extent of the Congo Basin, central quadrant of the $\mathrm{Cu}-$ vette Centrale, and locations of sampling stations used for validation (of DOC, discharge, and partial pressure of $\mathrm{CO}_{2}$ ) along the Congo and Oubangui River (in italics).

resenting the maximal fraction of floodplains (MFF) and the maximal fraction of swamps (MFS) (Sect. 2.2) and to recalibrate the river-routing module of ORCHILEAK (Sect. 2.3). All of the processes represented in ORCHILEAK remain identical to those previously represented for the Amazon ORCHILEAK (Lauerwald et al., 2017; Hastie et al., 2019). In the following methodology sections, we describe the following: Sect. 2.1 - Congo Basin description; Sect. 2.2 - development of floodplain and swamp forcing files; Sect. 2.3 - calibration of hydrology; Sect. 2.4 - simulation set-up; Sect. 2.5 - evaluation and analysis of simulated fluvial C fluxes; and Sect. 2.6 - calculating the net carbon balance of the Congo Basin. For a full description of the ORCHILEAK model, please see Lauerwald et al. (2017).

\subsection{Congo Basin description}

The Congo Basin is the world's second largest area of contiguous tropical rainforest and second largest river basin (Fig. 1), covering an area of $3.7 \times 10^{6} \mathrm{~km}^{2}$, with a mean discharge of around $42000 \mathrm{~m}^{-3} \mathrm{~s}^{-1}$ (O'Loughlin et al., 2013) and a variation between 24700 and $75500 \mathrm{~m}^{-3} \mathrm{~s}^{-1}$ across months (Coynel et al., 2005).

The major climate (ISMSIP2b; Frieler et al., 2017; Lang et al., 2017) and land cover (LUH-CMIP5) characteristics of the Congo Basin for the present day (1981-2010) are shown in Fig. 2. The mean annual temperature is $25.2^{\circ} \mathrm{C}$ but with considerable spatial variation from a low of $18.4{ }^{\circ} \mathrm{C}$ to a high of $27.2^{\circ} \mathrm{C}$ (Fig. 2a), while mean annual rainfall is $1520 \mathrm{~mm}$, varying from 733 to $4087 \mathrm{~mm}$ (Fig. 2b). ORCHILEAK prescribes 13 different plant functional types (PFTs). Land use is mixed with tropical broadleaved evergreen (PFT2, Fig. 1c), 

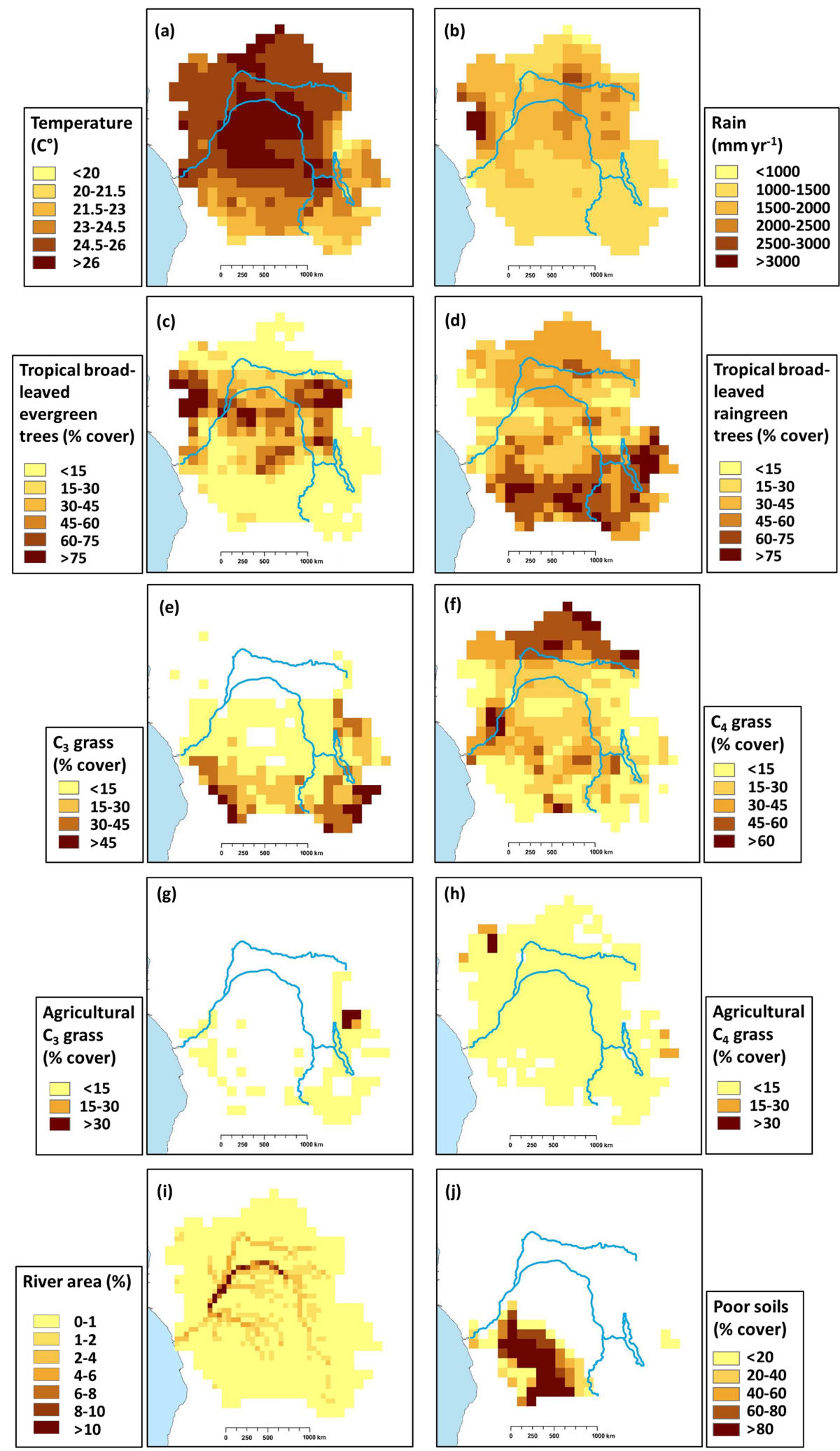

Figure 2. Present-day (1981-2010) spatial distribution of the principal climate and land use drivers used in ORCHILEAK across the Congo Basin; (a) mean annual temperature $\left({ }^{\circ} \mathrm{C}\right)$, (b) mean annual rainfall $\left(\mathrm{mm} \mathrm{yr}^{-1}\right),(\mathbf{c}-\mathbf{h})$ mean annual maximum vegetated fraction for PFTs 2 , $3,10,11,12$, and 13, respectively; (i) river area; and (j) poor soils. All are at a resolution of $1^{\circ}$ except for river area $\left(0.5^{\circ}\right)$. 
tropical broadleaved rain green (PFT3, Fig. 1d), $\mathrm{C}_{3}$ grass (PFT10, Fig. 2e), and $\mathrm{C}_{4}$ grass (PFT11, Fig. 2f) covering a maximum of $26 \%, 35 \%, 8 \%$, and $25 \%$ of the basin area, respectively. Most published estimates for land cover follow national boundaries, so we can make broad comparisons with published estimates for the Democratic Republic of Congo (DRC). For example, our value for total forest cover for the DRC (65\%) is close to the $67 \%$ and $68 \%$ values estimated by the Congo Basin Forest Partnership (CBFP, 2009) and Potapov et al. (2012), respectively. Agriculture covers only a small proportion of the basin according to the LUH dataset that is based on FAO cropland area statistics, with $\mathrm{C}_{3}$ (PFT12, Fig. 2g) and $\mathrm{C}_{4}$ (PFT13, Fig. 2h) agriculture making up a maximum basin area of $0.5 \%$ and $2 \%$, respectively. In reality, a larger fraction of the basin is composed of small-scale and rotational agriculture (Tyukavina et al., 2018). The ORCHILEAK model also has a "poor soils" forcing file (Fig. 2j) which prescribes reduced decomposition rates in soils with low-nutrient and low-pH soils such as Podzols and Arenosols (Lauerwald et al., 2017). This file is developed from the Harmonized World Soil Database (FAO/IIASA/ISRIC/ISS-CAS/JRC, 2009).

\subsection{Development of floodplain and swamp forcing files}

In ORCHILEAK, water in the river network can be diverted to two types of wetlands: floodplains and swamps. In each grid wherein a floodplain exists, a temporary water body can be formed adjacent to the river and is fed by the river once bankfull discharge (see Sect. 2.3) is exceeded. In grids wherein swamps exist, a constant proportion of river discharge is fed into the base of the soil column; ORCHILEAK does not explicitly represent a groundwater reservoir, so this imitates the hydrological coupling of swamps and rivers through the groundwater table. The maximal proportions of each grid which can be covered by floodplains and swamps are prescribed by the maximal fraction of floodplain (MFF) and the maximal fraction of swamp (MFS) forcing files, respectively (Guimberteau et al., 2012). See also Lauerwald et al. (2017) and Hastie et al. (2019) for further details. We created an MFF forcing file for the Congo Basin derived from the Global Wetlands ${ }^{\mathrm{v} 3}$ database, which includes the $232 \mathrm{~m}$ resolution tropical wetland map of Gumbricht et al. (2017) (Fig. 3a and b). We firstly amalgamated all the categories of wetland (which include floodplains and swamps) before aggregating them to a resolution of $0.5^{\circ}$ (the resolution at which the floodplain and swamp forcing files are read by ORCHILEAK), assuming that this represents the maximum extent of inundation in the basin. This results in a mean MFF of $10 \%$; i.e. a maximum of $10 \%$ of the surface area of the Congo Basin can be inundated with water. This is identical to the mean MFF value of $10 \%$ produced with the Global Lakes and Wetlands Database, GLWD (Lehner and Döll, 2004; Borges et al., 2015b). We also created an MFS forcing file from the same dataset (Fig. 3c and d), merg- ing the "swamps" and "fens" wetland categories (although note that there are virtually no fens in the Congo Basin) from the Global Wetlands ${ }^{\mathrm{v} 3}$ database (Gumbricht et al., 2017) and again aggregating them to a $0.5^{\circ}$ resolution. Please see Table 1 of Gumbricht et al. (2017) for further details.

\subsection{Calibration of hydrology}

As the main driver of the export of $\mathrm{C}$ from the terrestrial to the aquatic system, it is crucial that the model can represent present-day hydrological dynamics, at the very least on the main stem of the Congo. As this study is primarily concerned with decadal to centennial timescales our priority was to ensure that the model can accurately recreate observed mean annual discharge at the most downstream gauging station at Brazzaville. We also tested the model's ability to simulate observed discharge seasonality and flood dynamics. Moreover, no data are available with which to directly evaluate the simulation of $\mathrm{DOC}$ and $\mathrm{CO}_{2}$ leaching from the soil to the river network, and thus we tested the model's ability to recreate the spatial variation of observed riverine DOC concentrations and $p \mathrm{CO}_{2}$ at specific stations where measurements are available (Borges at al., 2015b; Bouillon et al., 2012, 2014; locations shown in Fig. 1), with the river DOC and $\mathrm{CO}_{2}$ concentration being regarded as an integrator of the $\mathrm{C}$ transport at the terrestrial-aquatic interface.

We first ran the model for the present-day period, defined as 1990 to 2005-2010 depending on which climate forcing data were applied, using four climate forcing datasets, namely ISIMIP2b (Frieler et al., 2017), Princeton GPCC (Sheffield et al., 2006), GSWP3 (Kim, 2017), and CRUNCEP (Viovy, 2018). We used ISIMIP2b for the historical and future simulations as it is the only climate forcing dataset to cover the full period (1861-2099). However, we compared it to other climate forcing datasets for the present day in order to gauge its ability to simulate observed discharge on the Congo River at Brazzaville (Table A1). Without calibration, the majority of the different climate forcing model runs performed poorly and were unable to accurately represent the seasonality and mean monthly discharge at Brazzaville (Table A1). The best-performing climate forcing dataset was ISIMIP2b, followed by Princeton GPCC, with root mean square errors (RMSEs) of $29 \%$ and $40 \%$ and a Nash-Sutcliffe efficiency (NSE) of 0.20 and -0.25 , respectively. NSE is a statistical coefficient specifically used to test the predictive skill of hydrological models (Nash and Sutcliffe, 1970).

For ISIMIP2b we further calibrated key hydrological model parameters, namely the constants (tau, $\tau$ ) which help to control the water residence time of the groundwater (slow reservoir), headwaters (fast reservoir), and floodplain reservoirs in order to improve the simulation of observed discharge at Brazzaville and Oubangui (Table 2). To do so, we tested different combinations of $\tau$ values for the three reservoirs, eventually settling on $1,0.5$, and 0.5 (d) for the slow, 

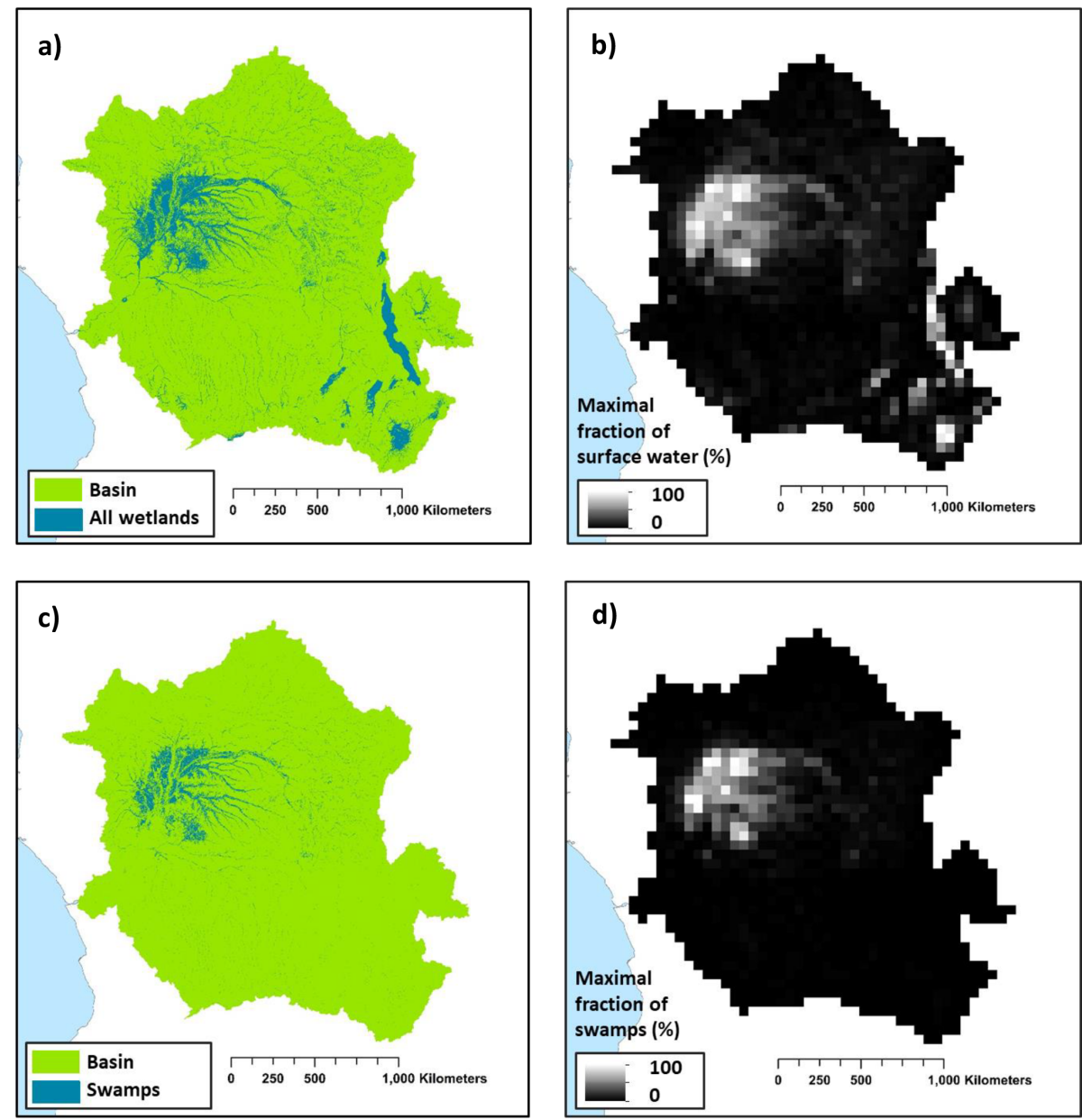

Figure 3. (a) Wetland extent (from Gumbricht et al., 2017). (b) The new maximal fraction of floodplain (MFF) forcing file developed from (a). (c) The swamp (including fens) category within the Congo Basin from Gumbricht et al. (2017). (d) The new maximal fraction of swamp (MFS) forcing file developed from (c). Panels (a) and (b) are at the same resolution as the Gumbricht dataset (232 m), while panels (b) and (d) are at a resolution of $0.5^{\circ}$. Note that $0.5^{\circ}$ is the resolution of the subunit basins in ORCHILEAK (Lauerwald et al., 2015), with each $1^{\circ}$ grid containing four sub-basins.

fast, and floodplain reservoirs, respectively, with all three being reduced compared to those values used in the original ORCHILEAK calibration for the Amazon (Lauerwald at al., 2017). The actual residence time of each reservoir is calculated at each time step. The residence time of the flooded reservoir, for example, is a product of $\tau_{\text {flood }}$, a topographical index, and the flooded fraction of the grid cell.

In order to calibrate the simulated discharge against observations, we first modified the flood dynamics of ORCHILEAK in the Congo Basin for the present day by adjusting bankfull discharge (streamr 50 th; Lauerwald et al., 2017) and the 95th percentile of water level heights (floodh 95 th). As in previous studies on the Amazon Basin (Lauerwald et al., 2017; Hastie et al., 2019) we defined bankfull discharge, i.e. the threshold discharge at which floodplain inundation starts (i.e. overtopping of banks), as the median discharge (50th percentile i.e. streamr 50 th) of the present-day climate forcing period (1990 to 2005). After re-running each model parametrization (different $\tau$ values) to obtain those bankfull discharge values, we calculated floodh 95 th over the simulation period for each grid cell (Table 1). This value is assumed to represent the water level over the riverbanks at which the maximum horizontal extent of floodplain inundation is reached. We then ran the model for a final time and validated the outputs against discharge data at Brazzaville (Cochonneau et al., 2006; Fig. 1). This procedure was repeated iteratively with the ISIMIP2b climate forcing with modifying the $\tau$ value of each reservoir in order to find the best-performing parametrization.

We firstly compared simulated versus observed discharge at Brazzaville (NSE, RMSE; Table 2), before using the data of Bouillon et al. (2014) to further validate discharge at Bangui (Fig. 1) on the main tributary Oubangui. In addition, we compared the simulated seasonality of flooded area against 
Table 1. Main forcing files used for simulations.

\begin{tabular}{|c|c|c|c|}
\hline Variable & $\begin{array}{r}\text { Spatial } \\
\text { resolution }\end{array}$ & $\begin{array}{l}\text { Temporal } \\
\text { resolution }\end{array}$ & Data source \\
\hline $\begin{array}{l}\text { Rainfall, incoming shortwave and } \\
\text { longwave radiation, air temperature, } \\
\text { relative humidity and air pressure } \\
\text { (close to the surface), wind speed }(10 \mathrm{~m} \\
\text { above the surface) }\end{array}$ & $1^{\circ}$ & $1 \mathrm{~d}$ & $\begin{array}{l}\text { ISIMIP2b, IPSL-CM5A-LR } \\
\text { model outputs for RCP6.0 } \\
\text { (Frieler et al., 2017) }\end{array}$ \\
\hline Land cover (and change) & $0.5^{\circ}$ & annual & LUH-CMIP5 \\
\hline Poor soils & $0.5^{\circ}$ & annual & $\begin{array}{l}\text { Derived from HWSD v } 1.1 \\
\text { (FAO/IIASA/ISRIC/ISS- } \\
\text { CAS/JRC, 2009) }\end{array}$ \\
\hline Streamflow directions & $0.5^{\circ}$ & annual & $\begin{array}{l}\text { STN-30p (Vörösmarty et al., } \\
\text { 2000) }\end{array}$ \\
\hline $\begin{array}{l}\text { Floodplain and swamp fraction in } \\
\text { each grid (MFF and MFS) }\end{array}$ & $0.5^{\circ}$ & annual & $\begin{array}{l}\text { Derived from the wetland high- } \\
\text { resolution data of Gumbricht et } \\
\text { al. (2017) }\end{array}$ \\
\hline River surface areas & $0.5^{\circ}$ & annual & Lauerwald et al. (2015) \\
\hline Bankfull discharge (streamr 50 th $)$ & $1^{\circ}$ & annual & $\begin{array}{l}\text { Derived from calibration with } \\
\text { ORCHILEAK (see Sect. 2.3) }\end{array}$ \\
\hline $\begin{array}{l}\text { 95th percentile of water table height } \\
\text { over floodplain (floodh } \\
95 \text { th) }\end{array}$ & $1^{\circ}$ & annual & $\begin{array}{l}\text { Derived from calibration with } \\
\text { ORCHILEAK (see Sect. 2.3) }\end{array}$ \\
\hline
\end{tabular}

Table 2. Performance statistics for the modelled versus observed seasonality of discharge at Brazzaville and Bangui, as well as flooded area in Cuvette Centrale. Observed flooded area is from GIEMS (Papa et al., 2010; Becker et al., 2018).

\begin{tabular}{|c|c|c|c|c|c|}
\hline Station & RMSE & NSE & $R^{2}$ & $\begin{array}{r}\text { Simulated mean } \\
\text { monthly discharge } \\
\left(\mathrm{m}^{3} \mathrm{~s}^{-1}\right)\end{array}$ & $\begin{array}{r}\text { Observed mean } \\
\text { monthly discharge } \\
\left(\mathrm{m}^{3} \mathrm{~s}^{-1}\right)\end{array}$ \\
\hline Brazzaville & $23 \%$ & 0.66 & 0.84 & 38944 & 40080 \\
\hline \multirow[t]{2}{*}{ Bangui } & $59 \%$ & 0.31 & 0.88 & 1448 & 2923 \\
\hline & & & & $\begin{array}{r}\text { Simulated mean } \\
\text { monthly flooded area } \\
\left(10^{3} \mathrm{~km}^{2}\right)\end{array}$ & $\begin{array}{r}\text { Observed mean } \\
\text { monthly flooded area } \\
\left(10^{3} \mathrm{~km}^{2}\right)\end{array}$ \\
\hline $\begin{array}{l}\text { Flooded } \\
\text { area } \\
\text { (Cuvette } \\
\text { Centrale) }\end{array}$ & $272 \%$ & -1.44 & 0.67 & 44 & 14 \\
\hline
\end{tabular}

the satellite-derived dataset GIEMS (Prigent et al., 2007; Becker et al., 2018) within the Cuvette Centrale wetlands (Fig. 1).

\subsection{Simulation set-up}

A list of the main forcing files used, along with data sources, is presented in Table 1. The derivation of the floodplains and swamps (MFF and MFS) is described in Sect. 2.2, while the calculation of bankfull discharge ( streamr $_{50 \text { th }}$ ) and the 95th percentile of water table height over floodplain (floodh95th) (Table 1) is described in Sect. 2.3.

\subsubsection{Soil carbon spin-up}

ORCHILEAK includes a soil module, primarily derived from ORCHIDEE-SOM (Camino-Serrano et al., 2018). The soil module has three different pools of soil DOC: the passive, slow, and active pool, and these are defined by their source material and residence times $\left(\tau_{\text {carbon }}\right)$. ORCHILEAK 
also differentiates between flooded and non-flooded soils as well as the decomposition rates of DOC, soil organic carbon (SOC), and litter being reduced (3 times lower) in flooded soils. In order for the soil $\mathrm{C}$ pools to reach steady state, we spun up the model for around 9000 years with fixed land use representative of 1861 and looping over the first 30 years of the ISMSIP2b climate forcing data (1861-1890). During the first 2000 years of spin-up, we ran the model with an atmospheric $\mathrm{CO}_{2}$ concentration of $350 \mu \mathrm{atm}$ and default soil $\mathrm{C}$ residence times $\left(\tau_{\text {carbon }}\right)$ halved, which allowed it to approach steady state more rapidly. Following this, we ran the model for a further 7000 years, reverting to the default $\tau_{\text {carbon }}$ values. At the end of this process, the soil $\mathrm{C}$ pools had reached approximately steady state, with $<0.02 \%$ change in each pool over the final century of the spin-up.

\subsubsection{Transient simulations}

After the spin-up, we ran a historical simulation from 1861 until the present day, which is 2005 in the case of the ISIMIP2b climate forcing data. We then ran a future simulation until 2099 using the final year of the historical simulation as a restart file. In both of these simulations, climate, atmospheric $\mathrm{CO}_{2}$, and land cover change were prescribed as fully transient forcings according to the RCP6.0 scenario. For climate variables, we used the IPSL-CM5A-LR model outputs for RCP6.0 bias-corrected by the ISIMIP2b procedure (Frieler et al., 2017; Lange, 2017), while land use change was taken from the 5th Coupled Model Intercomparison Project (CMIP5). As our aim is to investigate longterm trends, we calculated 30-year running means of simulated $\mathrm{C}$ flux outputs in order to smooth interannual variations. RCP6.0 is an emissions pathway that leads to a stabilization of radiative forcing at 6.0 watts per square metre $\left(\mathrm{W} \mathrm{m}^{-2}\right)$ in the year 2100 without exceeding that value in prior years (Masui et al., 2011). It is characterized by intermediate energy intensity, substantial population growth, middle to high $\mathrm{C}$ emissions, increasing cropland area to 2100 , and decreasing natural grassland area (van Vuuren et al., 2011). In the paper which describes the development of the future land use change scenarios under RCP6.0 (Hurtt et al., 2011), it is shown that land use change is highly sensitive to land use model assumptions, such as whether or not shifting cultivation is included. The LUH1 reconstruction, for instance, indicates shifting cultivation affecting all of the tropics with a residence time of agriculture of 15 years, whereas the review from Heinimann et al. (2017) revised the area of this type of agriculture downwards, with generally low values in the Congo except in the northeast and southeast, but suggested a shorter turnover of agriculture of only 2 years. In view of such uncertainties, we did not include shifting agriculture in the model. Moreover, there is considerable uncertainty associated with the effect of future land use change in Africa (Hurtt et al., 2011). We chose RCP6.0 as it represents a no mitigation (middle to high emissions) scenario. Moreover, the ISIMIP2b data only provided two Representative Concentration Pathways (RCPs) at the time we performed the simulations: RCP2.6 (low emission) and RCP6.0.

With the purpose of separately evaluating the effects of land use change, climate change, and rising atmospheric $\mathrm{CO}_{2}$, we ran a series of factorial simulations. In each simulation, one of these factors was fixed at its 1861 level (the first year of the simulation), or in the case of fixed climate change, we looped over the years 1861-1890. The outputs of these simulations (also 30-year running means) were then subtracted from the outputs of the main simulation (original run with all factors varied) so that we could determine the contribution of each driver (Fig. 11, Table 1).

\subsection{Evaluation and analysis of simulated fluvial C fluxes}

We first evaluated DOC concentrations and $p \mathrm{CO}_{2}$ at several locations along the Congo main stem (Fig. 1) and on the Oubangui River against the data of Borges at al. (2015b) and Bouillon et al. (2012, 2014). We also compared the various simulated components of the net C balance (e.g. NPP) of the Congo against values described in the literature (Williams et al., 2007; Lewis et al., 2009; Verhegghen et al., 2012; Valentini et al., 2014; Yin et al., 2017). In addition, we assessed the relationship between the interannual variation in presentday (1981-2010) C fluxes of the Congo Basin and variation in temperature and rainfall. This was done through linear regression using STATISTICA ${ }^{\mathrm{TM}}$. We found trends in several of the fluxes over the 30-year period (1981-2010) and thus detrended the time series with the "Detrend" function, part of the "SpecsVerification" package in R (R Core Team, 2013), before undertaking the statistical analysis focused on the climate drivers of interannual variability.

\subsection{Calculating the net carbon balance of the Congo Basin}

We calculated net ecosystem production (NEP) by summing the terrestrial and aquatic $\mathrm{C}$ fluxes of the Congo Basin (Eq. 1), while we incorporated disturbance fluxes (land use change flux and harvest flux) to calculate net biome production (NBP) (Eq. 2). Positive values of NBP and NEP equate to a net terrestrial $\mathrm{C}$ sink.

NEP is defined as follows:

$\mathrm{NEP}=\mathrm{NPP}+\mathrm{TF}-\mathrm{SHR}-\mathrm{FCO}_{2}-L E_{\text {Aquatic }}$,

where NPP is terrestrial net primary production, TF is the throughfall flux of DOC from the canopy to the ground, SHR is soil heterotrophic respiration (only that evading from the terra firme soil surface), $\mathrm{FCO}_{2}$ is $\mathrm{CO}_{2}$ evasion from the water surface, and $L E_{\text {Aquatic }}$ is the lateral export flux of $\mathrm{C}$ $\left(\mathrm{DOC}+\right.$ dissolved $\left.\mathrm{CO}_{2}\right)$ to the coast. NBP is equal to NEP except with the inclusion of the $\mathrm{C}$ lost (or possibly gained) via land use change (LUC) and crop harvest (HAR). Wood harvest is not included for logging and forestry practices, but 
during deforestation LUC, a fraction of the forest biomass is harvested and channelled to wood product pools with different decay constants. LUC includes land conversion fluxes and the lateral export of wood product biomass, assuming that wood products from deforestation are not consumed and released as $\mathrm{CO}_{2}$ over the Congo but in other regions:

$\mathrm{NBP}=\mathrm{NEP}-(\mathrm{LUC}+\mathrm{HAR})$.

\section{Results}

\subsection{Simulation of hydrology and aquatic carbon fluxes}

The final model configuration is able to closely reproduce the mean monthly discharge at Brazzaville (Fig. 4a, Table 2) and captures the seasonality moderately well (Fig. 4a, Table 2; $\mathrm{RMSE}=23 \%, R^{2}=0.84$ versus $\mathrm{RMSE}=29 \%, R^{2}=0.23$ without calibration; Table A1). At Bangui on the Oubangui River (Fig. 1), the model is able to closely recreate observed seasonality (Fig. 4b; RMSE $=59 \%, R^{2}=0.88$ ) but substantially underestimates the mean monthly discharge, with our value being only $50 \%$ of the observed. We produce reasonable NSE values of 0.66 and 0.31 for Brazzaville and Bangui, respectively, indicating that the model is moderately accurate in its simulation of seasonality.

We also evaluated the simulated seasonal change in flooded area in the central (approx. $200000 \mathrm{~km}^{2}$; Fig. 1) part of the Cuvette Centrale wetlands against the GIEMS inundation dataset (1993-2007, maximum inundation minus minimum or permanent water bodies; Prigent et al., 2007; Becker et al., 2018). While our model is able to represent the seasonality in flooded area relatively well $\left(R^{2}=0.75\right.$; Fig. 4 c) , it considerably overestimates the magnitude of flooded area relative to GIEMS (Fig. 4c, Table 2). However, the dataset that we used to define the MFF and MFS forcing files (Gumbricht et al., 2017) is produced at a higher resolution than GIEMS and will capture smaller wetlands than the GIEMS dataset; thus, the greater flooded area is to be expected. GIEMS is also known to underestimate inundation under vegetated areas (Prigent et al., 2007; Papa et al., 2010) and has difficulties capturing small inundated areas (Prigent et al., 2007; Lauerwald et al., 2017). Indeed, with the GIEMS data we produce an overall flooded area for the Congo Basin of just $3 \%$, less than one-third of that produced with the Gumbricht dataset (Gumbricht et al., 2017) or the GLWD (Lehner and Döll, 2004). As such, it is to be expected that there is a large RMSE (272\%; Table 2) between simulated flooded area and GIEMS; more importantly, the seasonality of the two is highly correlated $\left(R^{2}=0.67\right.$; Table 2$)$.

In Fig. 5, we compare simulated DOC concentrations at six locations (Fig. 1) along the Congo River and Oubangui tributary against the observations of Borges at al. (2015b). We show that we can recreate the spatial variation in the DOC concentration within the Congo Basin relatively closely with an $R^{2}$ of 0.74 and an RMSE of $24 \%$ (Fig. 5). We are also
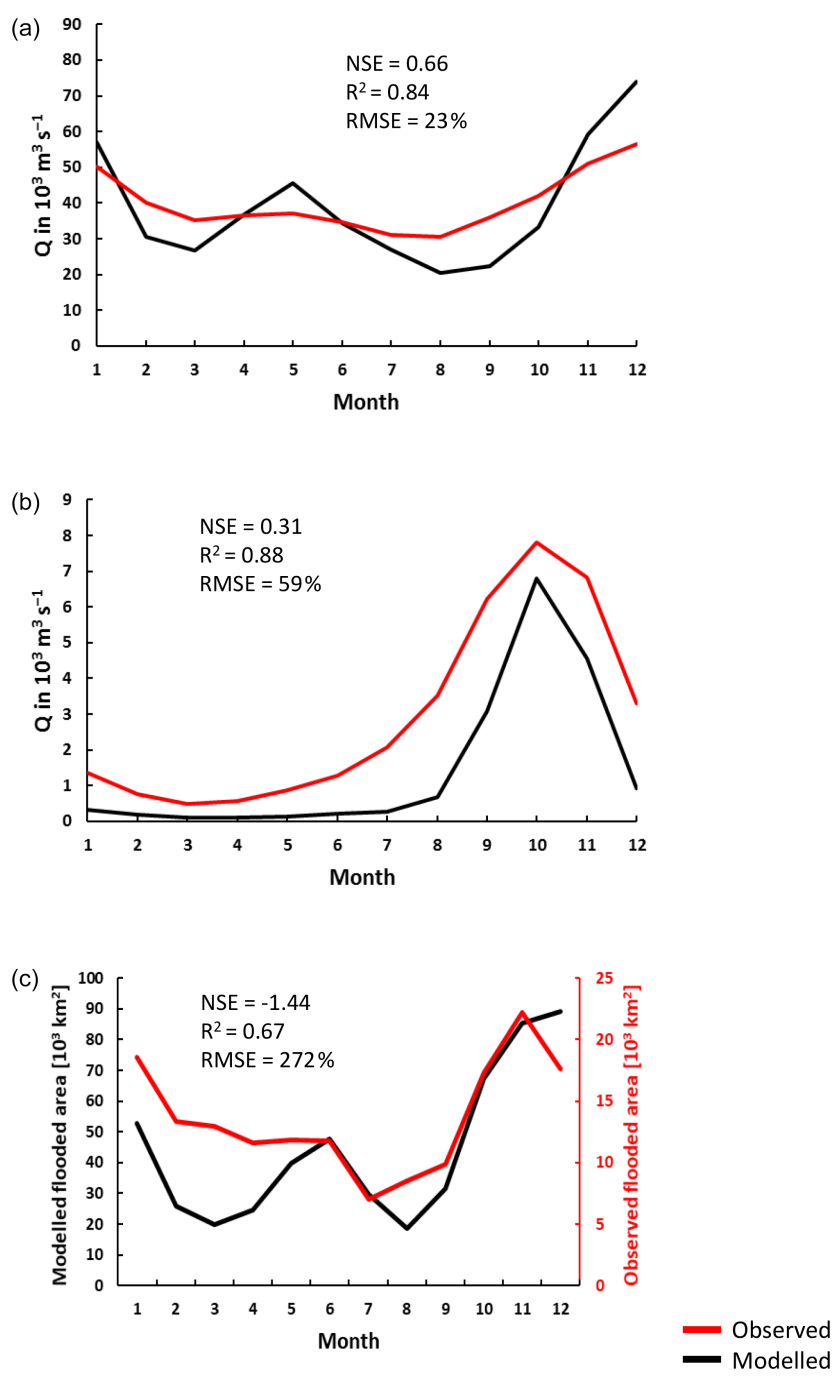

Figure 4. Seasonality of simulated versus observed discharge at (a) Brazzaville on the Congo (for the 1990-2005 monthly mean; Cochonneau et al., 2006), (b) Bangui on the Oubangui (20102012; Bouillon et al., 2014), and (c) flooded area in the central (approx. $200000 \mathrm{~km}^{2}$ ) part of the Cuvette Centrale wetlands versus GIEMS (1993-2007; Becker et al., 2018). The observed flooded area data represent the maximum minus minimum (permanent water bodies such as rivers) GIEMS inundation. See Fig. 1 for locations.

able to simulate the broad spatial pattern of $p \mathrm{CO}_{2}$ measured in the main-stem Congo reported by Borges et al. (2019). During the high-flow season (2009-2019 mean of 6 consecutive months of highest flow to account for interannual variation) we simulate a mean $p \mathrm{CO}_{2}$ of 3373 and $5095 \mathrm{ppm}$ at Kisangani and Kinshasa (Brazzaville), respectively, compared to the observed values of 2424 and $5343 \mathrm{ppm}$ during high water (measured in December 2013; Borges et al., 2019) (Table 3). Similarly, during the low-flow season (mean of 6 consecutive months of lowest flow, 2009-2019) we simulate a mean $p \mathrm{CO}_{2}$ of 1563 and $2782 \mathrm{ppm}$ at Kisangani and 


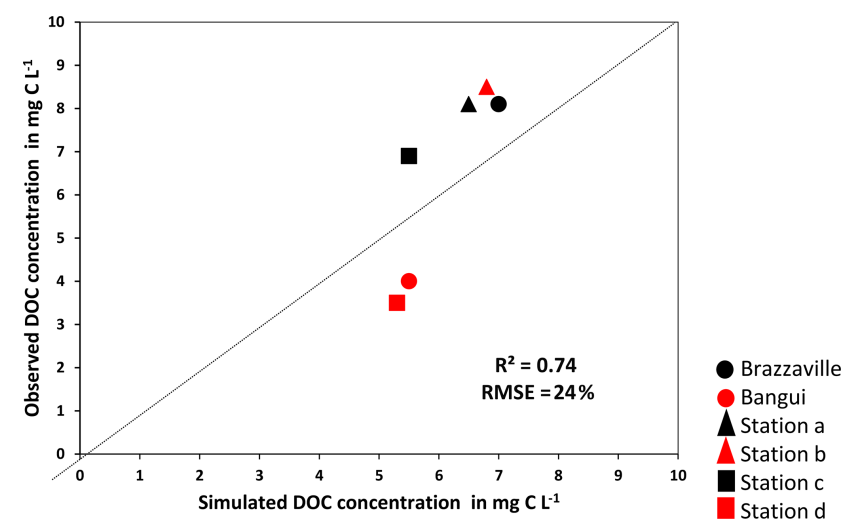

Figure 5. Observed (Borges et al., 2015a) versus simulated DOC concentrations at several sites along the Congo and Oubangui rivers. See Fig. 1 for locations. The simulated and observed DOC concentrations represent the median values across the particular sampling period at each location detailed in Borges et al. (2015a).

Kinshasa, respectively, compared to the observed values of 1670 and 2896 ppm during falling water (June 2014; Borges et al., 2019) (Table 3).

While we are able to recreate observed spatial differences in DOC and $p \mathrm{CO}_{2}$, as well as broad seasonal variations, we are not able to correctly predict the exact timing of the simulated highs and lows, a reflection of not fully capturing the hydrological seasonality. For example, our mean June $p \mathrm{CO}_{2}$ at Kinshasa (Brazzaville) is $4470 \mathrm{ppm}$, while Borges et al. measured a mean of $2896 \mathrm{ppm}$ (Table 3 ). However, our value for July of $2621 \mathrm{ppm}$ is much closer, and moreover our mean value for December of $5154 \mathrm{ppm}$ is relatively close to the observed value of $5343 \mathrm{ppm}$. Similarly, we fail to predict the timing of the June falling water at Kisangani (Table 3).

In Fig. 6, we compare simulated $p \mathrm{CO}_{2}$ against the observed monthly time series at Bangui on the Oubangui River (Bouillon et al., 2012, 2014), which as far as we are aware is the longest time series of $p \mathrm{CO}_{2}$ published (and accessible) from the Congo Basin, spanning March 2010 to March 2012 (with only the single month of June 2010 missing). Again, while the model fails to correctly predict the precise timing of the peak as with the Kinshasa and Kisangani datasets, the broad seasonal variation in $p \mathrm{CO}_{2}$ is captured, with the observed and modelled times series ranging from $227-4040$ and 415-2928 ppm, respectively (Fig. 6).

\subsection{Carbon fluxes along the Congo Basin for the present day}

For the present day (1981-2010) we estimate a mean annual terrestrial net primary production (NPP) of $5800 \pm$ $166 \mathrm{Tg} \mathrm{C} \mathrm{yr}^{-1}$ (standard deviation, SD) (Fig. 7), corresponding to a mean areal $\mathrm{C}$ fixation rate of approximately $1500 \mathrm{~g} \mathrm{C} \mathrm{m}^{-2} \mathrm{yr}^{-1}$ (Fig. 8a). We find a significant positive correlation between the interannual variation of NPP and

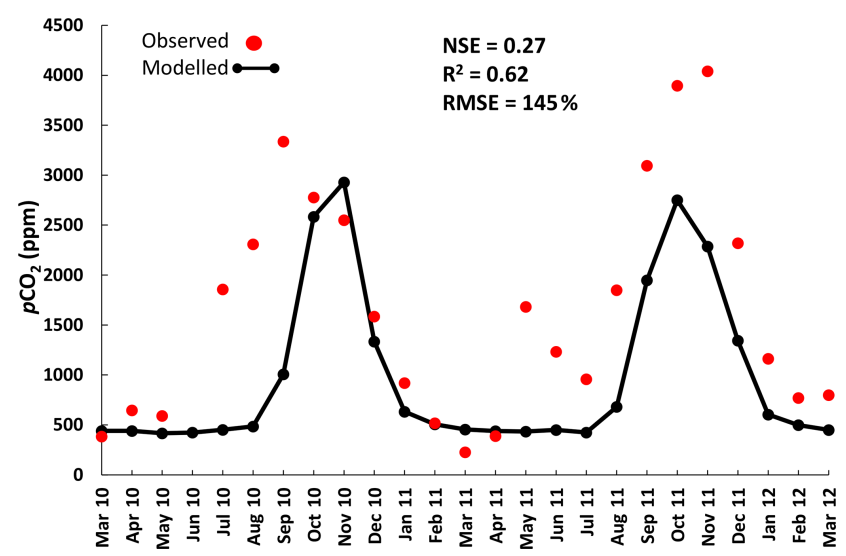

Figure 6. Time series of observed versus simulated $p \mathrm{CO}_{2}$ at Bangui on the River Oubangui. Observed data are from Bouillon et al. (2012, 2014).

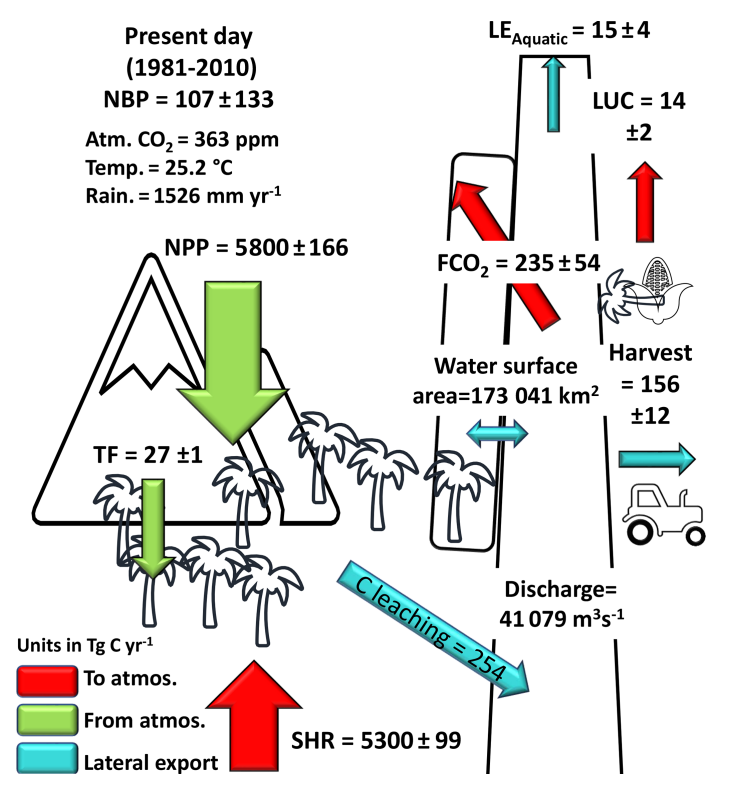

Figure 7. Annual $\mathrm{C}$ budget (NBP, net biome production) for the Congo Basin for the present day (1981-2010) simulated with ORCHILEAK; NPP is terrestrial net primary productivity, TF is throughfall, SHR is soil heterotrophic respiration, $\mathrm{FCO}_{2}$ is aquatic $\mathrm{CO}_{2}$ evasion, $\mathrm{C}$ leaching is $\mathrm{C}$ leakage to the land-ocean aquatic continuum $\left(\mathrm{FCO}_{2}+L E_{\text {Aquatic }}\right)$, LUC is the flux from land use change, and $L E_{\text {Aquatic }}$ is the export $\mathrm{C}$ flux to the coast. Range represents the standard deviation (SD) from 1981-2010.

rainfall (detrended $R^{2}=0.41, p<0.001$; Table A2) and a negative correlation between annual NPP and temperature (detrended $R^{2}=0.32, p<0.01$; Table A2). We also see considerable spatial variation in NPP across the Congo Basin (Fig. 8a).

We simulate a mean soil heterotrophic respiration (SHR) of $5300 \pm 99 \mathrm{Tg} \mathrm{C} \mathrm{yr}^{-1}$ across the Congo Basin (Fig. 7). Contrary to NPP, interannual variation in annual SHR is pos- 
Table 3. Observed (Borges et al., 2019) and modelled $p \mathrm{CO}_{2}$ (in ppm) at Kinshasa (Brazzaville) and Kisangani on the Congo River at various water levels.

\begin{tabular}{|c|c|c|c|c|c|c|}
\hline Location & $\begin{array}{c}\text { Observed } \\
p \mathrm{CO}_{2} \\
\text { high water } \\
\text { (December } \\
\text { 2013) }\end{array}$ & $\begin{array}{c}\text { Modelled } \\
p \mathrm{CO}_{2} \\
\text { high water } \\
\text { (December } \\
\text { Mean } \\
\text { 2009-2019) }\end{array}$ & $\begin{array}{c}\text { Modelled } \\
p \mathrm{CO}_{2} \\
\text { high-flow season } \\
\text { (mean of } 6 \\
\text { consecutive } \\
\text { months of highest } \\
\text { flow 2009-2019) }\end{array}$ & $\begin{array}{c}\text { Observed } \\
p \mathrm{CO}_{2} \\
\text { falling } \\
\text { water } \\
\text { (June } \\
2014)\end{array}$ & $\begin{array}{c}\text { Modelled } \\
p \mathrm{CO}_{2} \\
\text { falling } \\
\text { water } \\
\text { (June } \\
\text { mean } \\
\text { 2009-2019) }\end{array}$ & $\begin{array}{c}\text { Modelled } \\
p \mathrm{CO}_{2} \\
\text { low-flow season } \\
\text { (mean of } 6 \\
\text { consecutive } \\
\text { months of } \\
\text { lowest flow } \\
\text { 2009-2019) }\end{array}$ \\
\hline Kinshasa (Brazzaville) & 5343 & 5154 & 5095 & 2896 & 4470 & 2782 \\
\hline Kisangani & 2424 & 2166 & 3373 & 1670 & 3126 & 1563 \\
\hline
\end{tabular}
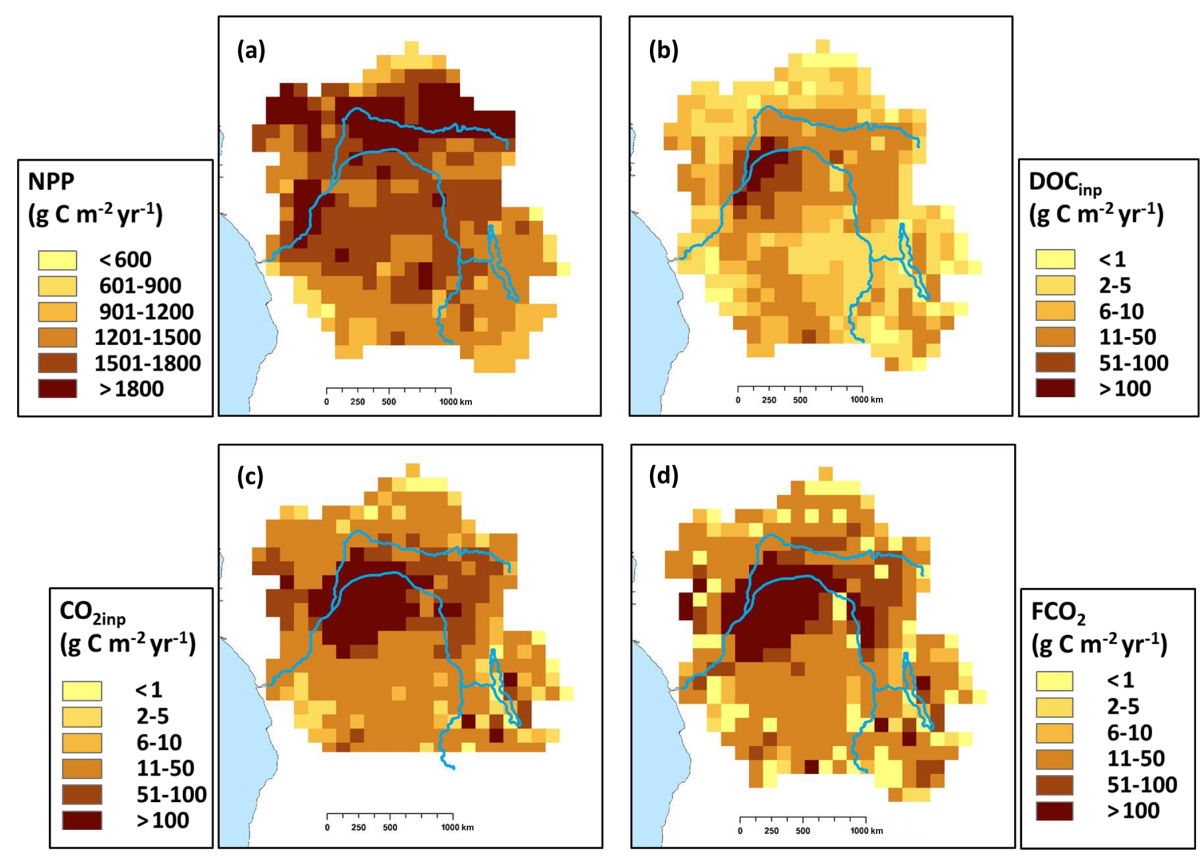

Figure 8. Present-day (1981-2010) spatial distribution of (a) terrestrial net primary productivity (NPP), (b) dissolved organic carbon export from soils and floodplain vegetation into the aquatic system $\left(\mathrm{DOC}_{\mathrm{inp}}\right),(\mathbf{c}) \mathrm{CO}_{2}$ leaching from soils and floodplain vegetation into the aquatic system $\left(\mathrm{CO}_{2 \text { inp }}\right)$, and (d) aquatic $\mathrm{CO}_{2}$ evasion $\left(\mathrm{FCO}_{2}\right)$. Main rivers are in blue. All are at a resolution of $1^{\circ}$.

itively correlated with temperature (detrended $R^{2}=0.57$, $p<0.0001$; Table A2) and inversely correlated with rainfall (detrended $R^{2}=0.10$ ), though the latter relationship is not significant $(p>0.05)$. We estimate a mean annual aquatic $\mathrm{CO}_{2}$ evasion rate of $1363 \pm 83 \mathrm{~g} \mathrm{C} \mathrm{m}^{-2} \mathrm{yr}^{-1}$, amounting to a total of $235 \pm 54 \mathrm{TgC}^{-1}$ across the total water surfaces of the Congo Basin (Fig. 7), and attribute $85 \%$ of this flux to flooded areas, meaning that only $32 \mathrm{Tg} \mathrm{C} \mathrm{yr}^{-1}$ is evaded directly from the river surface. Interannual variation in aquatic $\mathrm{CO}_{2}$ evasion (1981-2010) shows a strong positive correlation with rainfall (detrended $R^{2}=0.75, p<$ 0.0001; Table A2) and a weak negative correlation with temperature (detrended $R^{2}=0.09$, not significant, $p>0.05$ ). Aquatic $\mathrm{CO}_{2}$ evasion also exhibits substantial spatial variation (Fig. 8d), displaying a pattern similar to both ter- restrial DOC leaching $\left(\mathrm{DOC}_{\mathrm{inp}}\right)\left(R^{2}=0.81, p<0.0001\right.$; Fig. $8 \mathrm{~b})$ and terrestrial $\mathrm{CO}_{2}$ leaching $\left(\mathrm{CO}_{2 \text { inp }}\right)\left(R^{2}=0.96\right.$, $p<0.0001$, Fig. 8c) into the aquatic system, but not terrestrial NPP $\left(R^{2}=0.01, p<0.05\right.$; Fig. $\left.8 \mathrm{a}\right)$. We simulate a mean annual flux of DOC throughfall from the canopy of $27 \pm 1 \mathrm{TgC} \mathrm{Cyr}^{-1}$ and $\mathrm{C}\left(\mathrm{DOC}+\right.$ dissolved $\left.\mathrm{CO}_{2}\right)$ export flux to the coast of $15 \pm 4 \mathrm{Tg} \mathrm{C} \mathrm{yr}^{-1}$ (Fig. 7).

For the present day (1981-2010) we estimate a mean annual net ecosystem production (NEP) of $277 \pm 137 \mathrm{Tg} \mathrm{C} \mathrm{yr}^{-1}$ and a net biome production (NBP) of $107 \pm 133 \mathrm{Tg} \mathrm{C} \mathrm{yr}^{-1}$ (Fig. 7). Interannually, both NEP and NBP exhibit a strong inverse correlation with temperature (detrended NEP $R^{2}=$ $0.55, p<0.0001$, detrended NBP $\left.R^{2}=0.54, p<0.0001\right)$ and weak positive relationship with rainfall (detrended NEP $R^{2}=0.16, p<0.05$, detrended NBP $R^{2}=0.14, p<0.05$ ). 

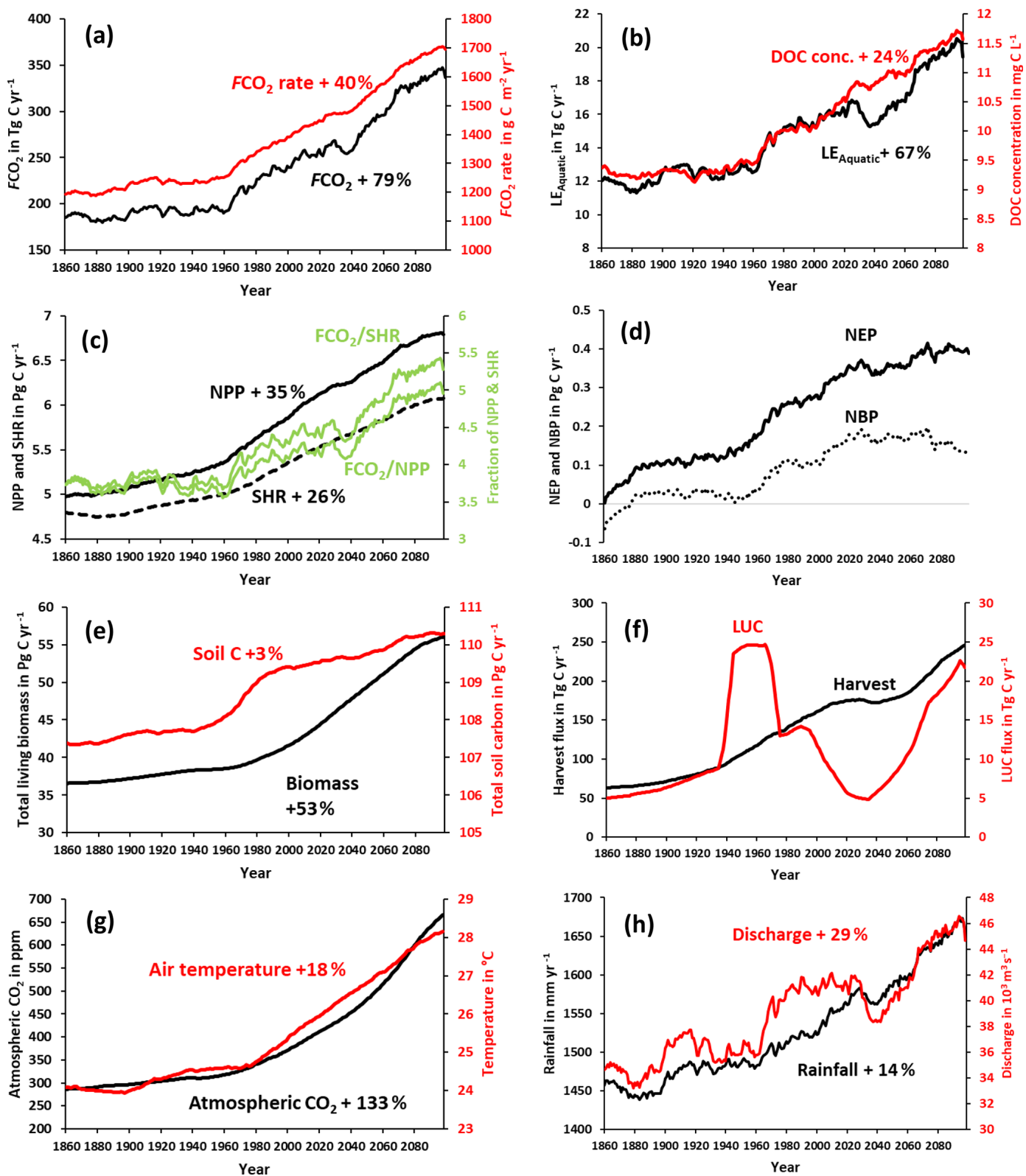

Figure 9. Simulation results for various C fluxes and stocks from 1861-2099 using IPSL-CM5A-LR model outputs for RCP6.0 (Frieler et al., 2017). All panels except for atmospheric $\mathrm{CO}_{2}$, biomass, and soil $\mathrm{C}$ correspond to 30 -year running means of simulation outputs. This was done in order to suppress interannual variation, as we are interested in longer-term trends.

Furthermore, we simulate a present-day (1981-2010) living biomass of $41 \pm 1 \mathrm{Pg} \mathrm{C}$ and a total soil C stock of $109 \pm 1 \mathrm{Pg} \mathrm{C}$.

\subsection{Long-term temporal trends in carbon fluxes}

We find an increasing trend in aquatic $\mathrm{CO}_{2}$ evasion (Fig. 9a) throughout the simulation period, rising slowly at first until the 1960s when the rate of increase accelerates. In total $\mathrm{CO}_{2}$ evasion rose by $79 \%$ from $186 \mathrm{Tg} \mathrm{C} \mathrm{yr}^{-1}$ at the start of the simulation (1861-1890 mean) (Fig. 10) to $333 \mathrm{Tg} \mathrm{C} \mathrm{yr}^{-1}$ at the end of this century (2070-2099 mean; Fig. 10), while the increase until the present day (1981-2010 mean) is $+26 \%$ (to $235 \mathrm{Tg} \mathrm{C} \mathrm{yr}^{-1}$ ), though these trends are not uniform across the basin (Fig. A1). The lateral export flux of $\mathrm{C}$ to the coast ( $\left.L E_{\text {Aquatic }}\right)$ follows a similar relative change (Fig. 9b), rising by $67 \%$ in total from $12 \mathrm{TgC}^{-1}$ (Fig. 10) to $15 \mathrm{Tg} \mathrm{Cyr}^{-1}$ for the present day and finally to $20 \mathrm{Tg} \mathrm{C} \mathrm{yr}^{-1}$ (2070-2099 mean; Fig. 10). This is greater than the equivalent increase in DOC concentration (24\%; Fig. 9b) due to the concurrent rise in rainfall (by $14 \%$; Fig. 9h) and in turn discharge (by $29 \%$; Fig. 9h). 


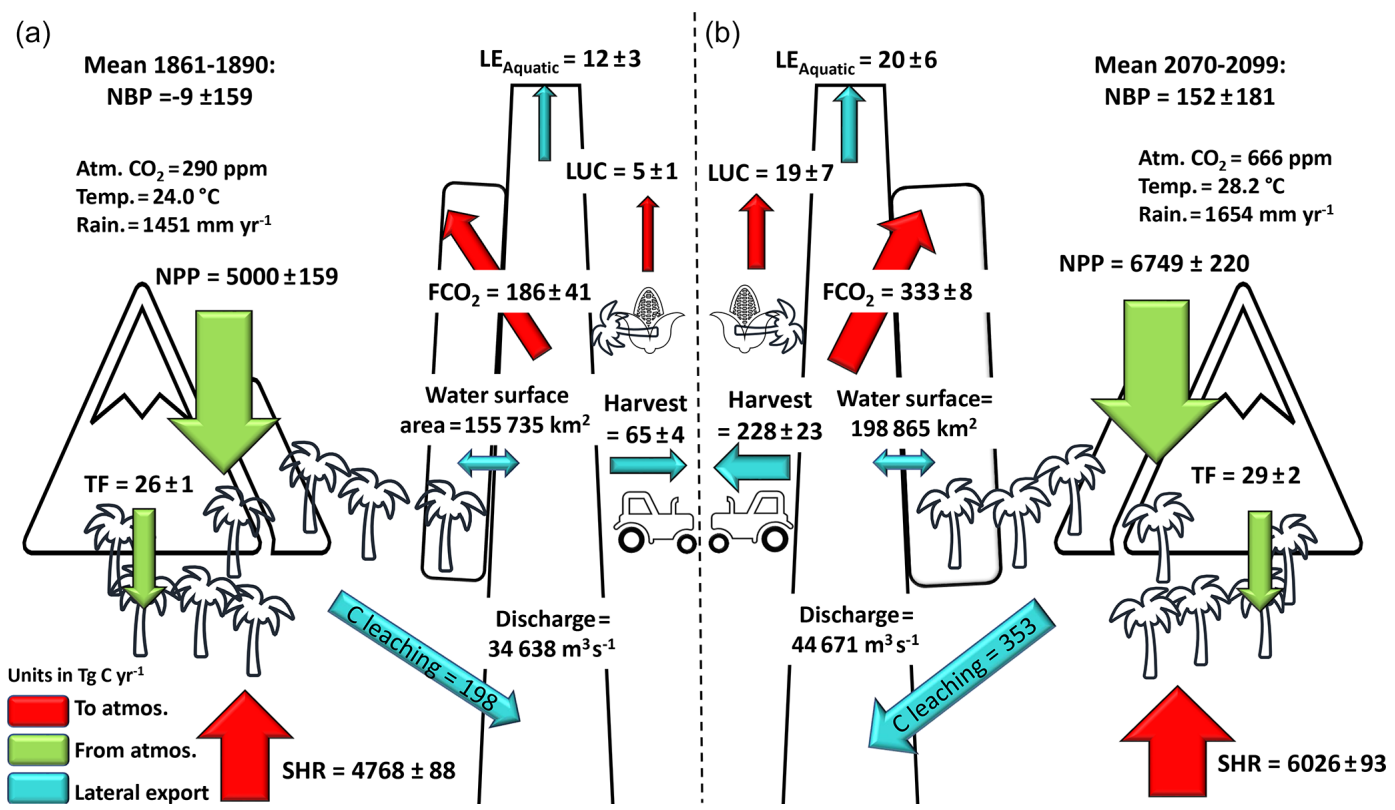

Figure 10. Annual C budget (NBP, net biome production) for the Congo Basin for (a) 1861-1890 and (b) 2070-2099, simulated with ORCHILEAK; NPP is terrestrial net primary productivity, TF is throughfall, $\mathrm{SHR}$ is soil heterotrophic respiration, $\mathrm{FCO}_{2}$ is aquatic $\mathrm{CO}_{2}$ evasion, $\mathrm{C}$ leaching is $\mathrm{C}$ leakage to the land-ocean aquatic continuum $\left(\mathrm{FCO}_{2}+L E_{\text {Aquatic }}\right)$, LUC is the flux from land use change, and $L E_{\text {Aquatic }}$ is the export $\mathrm{C}$ flux to the coast. Range represents the standard deviation (SD).

Terrestrial NPP and SHR also exhibit substantial increases of $35 \%$ and $26 \%$, respectively, across the simulation period and similarly rise rapidly after 1960 (Fig. 9c). NEP, NBP (Fig. 9d), and living biomass (Fig. 9e) follow roughly the same trend as NPP, but NEP and NBP begin to slow down or even level off around 2030, and in the case of NBP, we actually simulate a decreasing trend over approximately the final 50 years. Interestingly, the proportion of NPP lost to the LOAC also increases from approximately $3 \%$ to $5 \%$ (Fig. 9c). We also find that living biomass stock increases by a total of $53 \%$ from 1861 to 2099 . Total soil C also increases over the simulation but only by $3 \%$ from 107 to $110 \mathrm{Pg} \mathrm{Cyr}^{-1}$ (Fig. 9e). Emissions from land use change (LUC) show considerable decadal fluctuation, increasing rapidly in the second half of the 20th century and decreasing in the mid-21st century before rising again towards the end of the simulation (Fig. 9f). The harvest flux (Fig. 9f) rises throughout the simulation with the exception of a period in the mid-21st century during which it stalls for several decades. This is reflected in the change in land use areas from 1861-2099 (Fig. A2) during which the natural forest and grassland PFTs marginally decrease, while both $\mathrm{C}_{3}$ and $\mathrm{C}_{4}$ agricultural grassland PFTs increase.

\subsection{Drivers of simulated trends in carbon fluxes}

The dramatic increase in the concentration of atmospheric $\mathrm{CO}_{2}$ (Fig. 9g) and subsequent fertilization effect on terrestrial NPP have the greatest overall impact on all of the fluxes across the simulation period (Fig. 11). They are responsible for the vast majority of the growth in NPP, SHR, aquatic $\mathrm{CO}_{2}$ evasion, and the flux of $\mathrm{C}$ to the coast (Fig. 11a-d). The effect of LUC on these four fluxes is more or less neutral, while the impact of climate change is more varied. The aquatic fluxes (Fig. 11c and d) respond positively to an acceleration in the increase of both rainfall (and in turn discharge; Fig. 9h) and temperature (Fig. 9g) starting around 1970. From around 2020, the impact of climate change on the lateral flux of $\mathrm{C}$ to the coast (Fig. 11d) reverts to being effectively neutral, likely a response to a slowdown in the rise of rainfall and indeed a decrease in discharge (Fig. 9h), as well as perhaps the effect of temperature crossing a threshold. The response of the overall loss of terrestrial $\mathrm{C}$ to the LOAC (i.e. the ratio of LOAC to NPP; Fig. 11e) is relatively similar to the response of the individual aquatic fluxes, but crucially, climate change exerts a much greater impact, contributing substantially to an increase in the loss of terrestrial NPP to the LOAC in the 1960s and again in the second half of the 21 st century. These changes closely coincide with the pattern of rainfall and in particular with changes in discharge (Fig. 9h).

Overall temperature and rainfall increase by $18 \%$ and $14 \%$ from 24 to $28^{\circ} \mathrm{C}$ and 1457 to $1654 \mathrm{~mm}$, respectively, but in Fig. A2 one can see that this increase is non-uniform across the basin. Generally speaking, the greatest increase in temperature occurs in the south of the basin, while it is the east that sees the largest rise in rainfall (Fig. A2). Land use changes are similarly non-uniform (Fig. A2). 

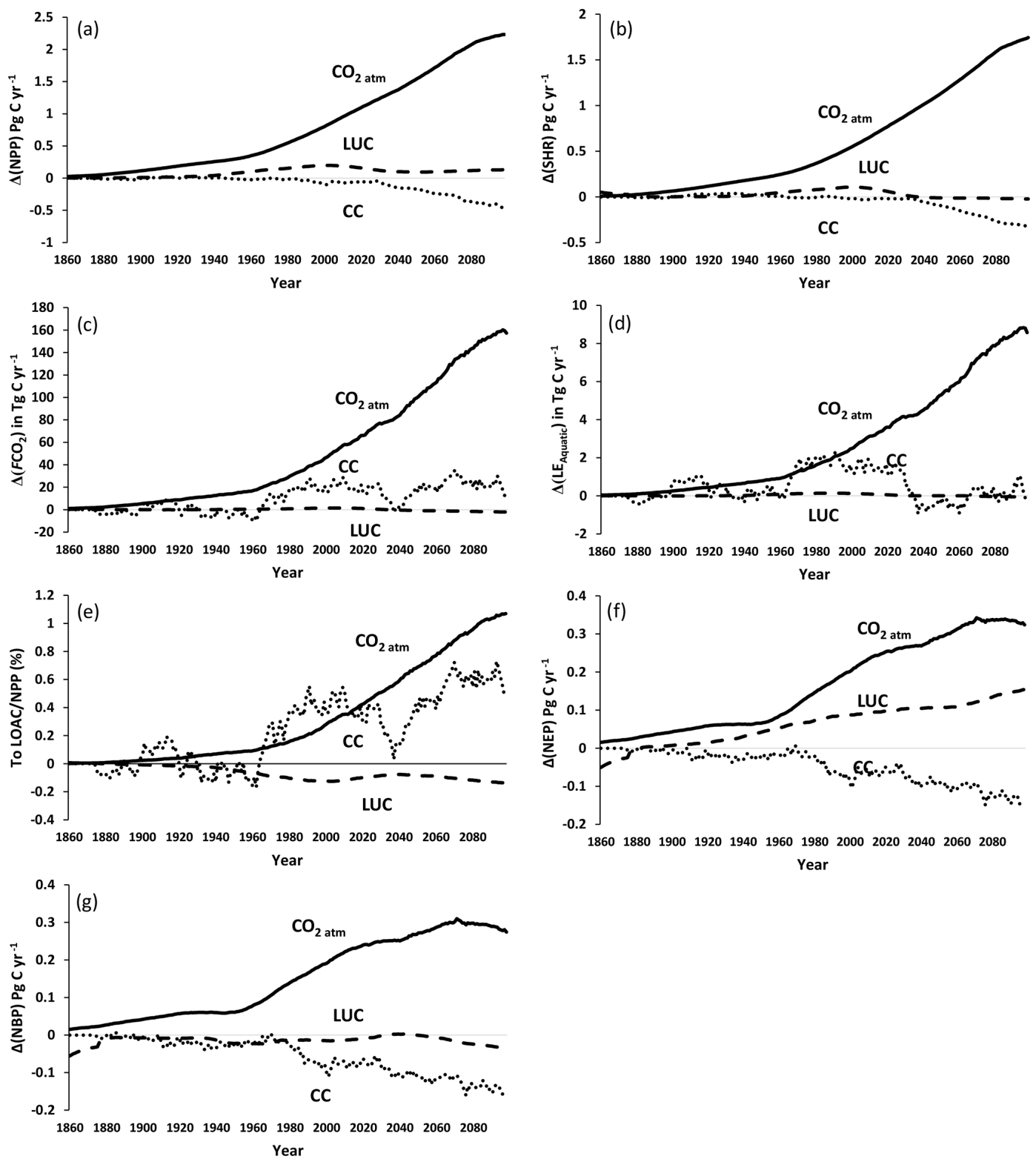

Figure 11. Contribution of the anthropogenic drivers atmospheric $\mathrm{CO}_{2}$ concentration $\left(\mathrm{CO}_{2}\right.$ atm $)$, climate change (CC), and land use change (LUC) to changes in the various carbon fluxes along the Congo Basin under IPSL-CM5A-LR model outputs for RCP6.0 (Frieler et al., 2017).

The response of NBP and NEP (Fig. 11f and g) to anthropogenic drivers is more complex. The simulated decrease in NBP towards the end of the run is influenced by a variety of factors; LUC and climate begin to have a negative effect on NBP (contributing to a decrease in NBP) at a similar time, while the positive impact (contributing to an increase in NBP) of atmospheric $\mathrm{CO}_{2}$ begins to slow down and eventually level off (Fig. 11g). LUC continues to have a positive effect on NEP (Fig. 11f) due to the fact that the expanding $\mathrm{C}_{4}$ crops have a higher NPP than forests, while it has an overall negative effect on NBP at the end of the simulation due to the inclusion of emissions from crop harvest.

\section{Discussion}

\subsection{Congo Basin carbon balance}

We simulate a mean present-day terrestrial NPP of approximately $1500 \mathrm{~g} \mathrm{C} \mathrm{m}^{-2} \mathrm{yr}^{-1}$ (Fig. 6), substantially larger than the MODIS-derived value of around $1000 \mathrm{~g} \mathrm{C} \mathrm{m}^{-2} \mathrm{yr}^{-1}$ from Yin et al. (2017) across central Africa, though it is important to note that satellite-derived estimates of NPP can underestimate the impact of $\mathrm{CO}_{2}$ fertilization, namely its positive effect on photosynthesis (De Kauwe et al., 2016; Smith et al., 2020). Our stock of the present-day living biomass of 
41.1 $\mathrm{PgC}$ is relatively close to the total Congo vegetation biomass of $49.3 \mathrm{Pg} C$ estimated by Verhegghen et al. (2012) based on the analysis of MERIS satellite data. Moreover, our simulated Congo Basin soil C stock of $109 \pm 1.1 \mathrm{Pg} \mathrm{C}$ is consistent with the approximately $120-130 \mathrm{PgC}$ across Africa between the latitudes $10^{\circ} \mathrm{S}$ and $10^{\circ} \mathrm{N}$ in the review of Williams et al. (2007), within which the Congo represents roughly $70 \%$ of the land area. Therefore, their estimate of soil C stocks across the Congo only would likely be marginally smaller than ours. It is also important to note that neither estimate of soil $\mathrm{C}$ stocks explicitly takes into account the newly discovered peat store of $30 \mathrm{Pg} \mathrm{C}$ (Dargie et al., 2017), and therefore both are likely to represent conservative values. In addition, Williams et al. (2007) estimate the combined fluxes from conversion to agriculture and cultivation to be around $100 \mathrm{Tg} \mathrm{C} \mathrm{yr}^{-1}$ in tropical Africa (largely synonymous with the Congo Basin), which is relatively close to our present-day estimate of harvesting + land use change flux of $170 \mathrm{Tg} \mathrm{C} \mathrm{yr}^{-1}$.

Our results suggest that $\mathrm{CO}_{2}$ evasion from the water surfaces of the Congo is sustained by the transfer of dissolved $\mathrm{CO}_{2}$ and DOC with 226 and $73 \mathrm{Tg} \mathrm{C}$, respectively, from wetland soils and vegetation to the aquatic system each year (1980-2010; Fig. 8). Moreover, we find that a disproportionate amount of this transfer occurs within the Cuvette Centrale wetland (Figs. 1 and 8 ) in the centre of the basin, in agreement with a recent study by Borges et al. (2019). In our study, this is due to the large areal proportion of inundated land, facilitating the exchange between soils and aquatic systems. Borges et al. (2019) conducted measurements of DOC and $p \mathrm{CO}_{2}$, amongst other chemical variables, along the Congo main stem and its tributaries from Kinshasa in the west of the basin (beside Brazzaville; Fig. 1) through the Cuvette Centrale to Kisangani in the east (close to station $\mathrm{d}$ in Fig. 1). They found that both DOC and $p \mathrm{CO}_{2}$ approximately doubled from Kisangani downstream to Kinshasa (Table 3) and demonstrated that this variation is overwhelmingly driven by fluvial-wetland connectivity, highlighting the importance of the vast Cuvette Centrale wetland in the aquatic $\mathrm{C}$ budget of the Congo Basin.

Our estimate of the integrated present-day aquatic $\mathrm{CO}_{2}$ evasion from the river surface of the Congo Basin $\left(32 \mathrm{TgC} \mathrm{Cr}^{-1}\right)$ is the same as that estimated by Raymond et al. (2013) (also $32 \mathrm{Tg} \mathrm{Cyr}^{-1}$ ), downscaled over the same basin area, but smaller than the $59.7 \mathrm{Tg} \mathrm{Cyr}^{-1}$ calculated by Lauerwald et al. (2015) and far smaller than that of Borges et al. (2015a) at 133-177 $\mathrm{Tg} \mathrm{C} \mathrm{yr}^{-1}$ or Borges et al. (2019) at $251 \pm 46 \mathrm{Tg} \mathrm{C} \mathrm{yr}^{-1}$. The recent study by Borges et al. (2019) is based on the most extensive dataset of Congo Basin $p \mathrm{CO}_{2}$ measurements to date and thus suggests that we substantially underestimate total riverine $\mathrm{CO}_{2}$ evasion. As previously discussed, we simulate the broad spatial and temporal variation in observed DOC and $p \mathrm{CO}_{2}$ (Borges et al., 2015a, b; Fig. 5, Table 3) relatively well. It is therefore somewhat surprising that our basin-wide estimate of riverine $\mathrm{CO}_{2}$ evasion is so different. Below we discuss some possible explanations for this discrepancy related to methodological differences and limitations.

One potential cause for the differences could be the river gas exchange velocity $k$. We applied a mean riverine gas exchange velocity $k_{600}$ of $3.5 \mathrm{~m} \mathrm{~d}^{-1}$, which is similar to the $2.9 \mathrm{~m} \mathrm{~d}^{-1}$ used by Borges et al. (2015a) but substantially smaller than the mean of approximately $8 \mathrm{~m} \mathrm{~d}^{-1}$ estimated across Strahler orders 1-10 in Borges et al. (2019) (taking the contributing water surface area of each Strahler order into account). A sensitivity analysis was performed in Lauerwald et al. (2017), which showed that in the physical approach of ORCHILEAK, $\mathrm{CO}_{2}$ evasion is not very sensitive to the $k$ value, unlike data-driven models. Namely, Lauerwald et al. (2017) showed that an increase or decrease in $k_{600}$ for rivers and swamps (flooded forests) of $50 \%$ only led to a $1 \%$ and $-4 \%$ change in total $\mathrm{CO}_{2}$ evasion, respectively. In ORCHILEAK, $k$ does have an important impact on $p \mathrm{CO}_{2}$; i.e. a lower $k$ value will increase $p \mathrm{CO}_{2}$, but this will also lead to a steeper water-air $\mathrm{CO}_{2}$ gradient and so ultimately to approximately the same $\mathrm{FCO}_{2}$ over time. In other words, over the scales covered in this research (the large catchment area and water residence times of the Congo), $\mathrm{FCO}_{2}$ is mainly controlled by the allochthonous inputs of carbon to the river network because by far the largest fraction of these $\mathrm{C}$ inputs is leaving the system via $\mathrm{CO}_{2}$ emission to the atmosphere (as opposed to being laterally transferred downstream). Therefore, we do not consider $k$ to be a major source of the discrepancy. Additionally, our $k_{600}$ value of $0.65 \mathrm{~m} \mathrm{~d}^{-1}$ for forested floodplains (based on Richey et al., 2002) compares well to recent a study which directly measured $k_{600}$ on two different flooded forest sites in the Amazon Basin, observing a range of 0.24 to $1.2 \mathrm{~m} \mathrm{~d}^{-1}$ (MacIntyre et al., 2019).

Another potential reason for our smaller riverine $\mathrm{CO}_{2}$ evasion could be river surface area. We simulate a mean presentday (1980-2010) total river surface area of $25900 \mathrm{~km}^{2} \mathrm{com}-$ pared to the value of $23670 \mathrm{~km}^{2}$ used in Borges et al. (2019, Supplement), so similarly we think that this can be discounted as a major source of discrepancy. However, it should be noted that both estimates are high compared to the recent estimate of $17903 \mathrm{~km}^{2}$ based on an analysis of Landsat images (Allen and Pavelsky, 2018).

The difference in our simulated riverine $\mathrm{CO}_{2}$ evasion compared to the empirically derived estimate of Borges et al. (2019) could be caused by the lack of representation of aquatic plants in the ORCHILEAK model. Borges et al. (2019) used the stable isotope composition of $\delta^{13} \mathrm{C}-$ DIC to determine the origin of dissolved $\mathrm{CO}_{2}$ in the Congo River system and found that the values were consistent with a DIC input from the degradation of organic matter, in particular from $\mathrm{C}_{4}$ plants. Crucially, they further found that the $\delta^{13} \mathrm{C}-\mathrm{DIC}$ values were unrelated to the contribution of terra firme $\mathrm{C}_{4}$ plants; rather, they were more consistent with the degradation of aquatic $\mathrm{C}_{4}$ plants, namely macrophytes. ORCHILEAK does not represent aquatic plants, and the wider 
LSM ORCHIDEE does not have an aquatic macrophyte PFT (though root respiration of floodplain plants for the PFTs represented is accounted for as a $\mathrm{C}$ source). This could at the very least partly explain our conservative estimate of river $\mathrm{CO}_{2}$ evasion given that tropical macrophytes have relatively high NPP. Rates as high as $3500 \mathrm{~g} \mathrm{C} \mathrm{m}^{-2} \mathrm{yr}^{-1}$ have been measured on floodplains in the Amazon (Silva et al., 2009). While this value is higher than the values simulated in the Cuvette Centrale by ORCHILEAK (Fig. 8), they are of the same order of magnitude, so this alone cannot fully explain the discrepancy compared to the results of Borges et al. (2019). In the Amazon Basin it has been shown that wetlands export approximately half of their gross primary production (GPP) to the river network compared to upland (terra firme) ecosystems, which only export a few percent (Abril et al., 2014). More importantly, Abril et al. (2014) found that tropical aquatic macrophytes export $80 \%$ of their GPP compared to just $36 \%$ for flooded forest. Therefore, the lack of a bespoke macrophyte PFT is indeed likely to be one reason for the discrepancy between our results and those of Borges but largely due to their particularly high export efficiency to the river-floodplain network as opposed to differences in NPP. While being a significant limitation, creating and incorporating a macrophyte PFT would be a substantial undertaking given that the authors are unaware of any published dataset which has systematically mapped their distribution and abundance. It is important to note that while ORCHILEAK does not include the export of $\mathrm{C}$ from aquatic macrophytes, it also neglects their NPP. Moreover, most aquatic macrophytes described in the literature have short ( $<1$ year) life cycles (Mitchel and Rogers, 1985). As such, while this model limitation is likely one of the causes for our relatively low estimate of riverine $\mathrm{CO}_{2}$ evasion, it will only have a limited net effect on our estimate of the overall annual $\mathrm{C}$ balance (NBP, NEP) of the Congo Basin.

Finally, another cause for the difference in riverine $\mathrm{CO}_{2}$ evasion could be that the resolution of ORCHILEAK $\left(0.5^{\circ}\right.$ river network and $1^{\circ}$ for $\mathrm{C}$ fluxes) is not sufficient to fully capture the dynamics of the smallest streams of the Congo Basin, which have been shown to have the highest DOC and $\mathrm{CO}_{2}$ concentrations (Borges et al., 2019). Indeed, ORCHILEAK typically does not simulate the highest observed $p \mathrm{CO}_{2}$ measurements of the smallest tributaries (i.e. $>16000 \mathrm{ppm}$ ). This is partly because for the fast reservoir (headwaters) in ORCHILEAK we assume full $p \mathrm{CO}_{2}$ equilibrium with the atmosphere over one full day, which prevents very high $p \mathrm{CO}_{2}$ values from building in the water column.

Despite these limitations, it is important to note that in our simulations, the evasion flux from rivers only contributes $15 \%$ of total aquatic $\mathrm{CO}_{2}$ evasion, and including the flux from wetlands and floodplains, we produce a total of $235 \mathrm{Tg} \mathrm{C} \mathrm{yr}^{-1}$. Moreover, the majority of this evasion occurs in the Cuvette Centrale (Fig. 8), which suggests that while ORCHILEAK fails to attribute a large portion of this flux to small rivers (owing to the coarse resolution of the river network) we nonetheless do capture the source of carbon. In other words, in ORCHILEAK the majority of this carbon evades directly from the floodplain and wetlands of the $\mathrm{Cu}$ vette Centrale as opposed to the small rivers.

Our simulated export of $\mathrm{C}$ to the coast of 15 (15.3) $\mathrm{Tg} \mathrm{C} \mathrm{yr}^{-1}$ is virtually identical to the TOC + DIC export estimated by Borges et al. (2015a) of $15.5 \mathrm{Tg} \mathrm{C} \mathrm{yr}^{-1}$, which is consistent with the fact that we simulate a similar spatial variation of DOC concentrations (see Figs. 8 and 1 for locations). It is also relatively similar to the $19{\mathrm{Tg} \mathrm{C} \mathrm{yr}^{-1}}^{-1}$ (DOC + DIC) estimated by Valentini et al. (2014) in their synthesis of the African carbon budget. Valentini et al. (2014) used the largely empirically based global nutrient export from the WaterSheds (NEWS) model framework, and they point out that Africa was underrepresented in the training data used to develop the regression relationships which underpin the model, and this could thus explain the small disagreement.

Of the total $15 \mathrm{Tg} \mathrm{Cyr}^{-1}$ exported to the coast, we simulate a $2.4 \mathrm{Tg} \mathrm{C} \mathrm{yr}^{-1}$ component of dissolved $\mathrm{CO}_{2}$, which is relatively similar to the empirically derived estimate of the total DIC export of $3.3 \mathrm{TgC}^{-1}$ calculated in Wang et al. (2013). According to Wang et al., dissolved $\mathrm{CO}_{2}$ accounts for the majority $\left(1.9 \mathrm{TgC}_{\mathrm{yr}}^{-1}\right)$, with the rest being the weathering derived flux of $\mathrm{HCO}_{3}^{-}$. Thus, the discrepancy between the two estimates is likely to be largely caused by our lack of accounting for the weathering-derived flux $\left(\mathrm{HCO}_{3}^{-}\right)$, which they estimate at $1.4 \mathrm{Tg} \mathrm{C} \mathrm{yr}^{-1}$. In summary, despite this model limitation the results of Wang et al. (2013) suggest that we still capture the majority of the DIC flux.

\subsection{Trends in terrestrial and aquatic carbon fluxes}

There are relatively sparse observed data available on the long-term trends of terrestrial $\mathrm{C}$ fluxes in the Congo. Yin et al. (2017) used MODIS data to estimate NPP between 2001 and 2013 across central Africa. They found that NPP increased on average by $10 \mathrm{~g} \mathrm{C} \mathrm{m}^{-2}$ per year, while we simulate an average annual increase of $4 \mathrm{~g} \mathrm{C} \mathrm{m}^{-2} \mathrm{yr}^{-1}$ over the same period across the Congo Basin. The two values are not directly comparable as they do not cover precisely the same geographic area, but it is encouraging that our simulations exhibit a similar trend as remote sensing data. As previously noted, MODIS-derived estimates of NPP do not fully include the effect of $\mathrm{CO}_{2}$ fertilization (de Kauwe et al., 2016), whereas ORCHILEAK does. Thus, the MODIS NPP product may underestimate the increasing trend in NPP, which would bring our modelled trend further away from this dataset. On the other hand, forest degradation effects and recent droughts have been associated with a decrease in greenness (Zhou et al., 2014) and above-ground biomass loss (Qie et al., 2019) in tropical forests. 
Up to a point, our results also concur with estimates based on the upscaling of biomass observations (Lewis et al., 2009; Hubau et al., 2020). Lewis et al. (2009) upscaled forest plot measurements to determine that intact tropical African forests represented a net uptake of approximately $300 \mathrm{Tg} \mathrm{Cyr}^{-1}$ between 1968 and 2007, and this is consistent with our NEP estimate of $275 \mathrm{Tg} \mathrm{C} \mathrm{yr}^{-1}$ over the same period. However, more recently an analysis based on an extension of the same dataset found that the above-ground $\mathrm{C}$ sink in tropical Africa was relatively stable from 1985 to 2015 (Hubau et al., 2020).

A major source of the uncertainty associated with future projections of NPP and NEP comes from our limited understanding and representation of the $\mathrm{CO}_{2}$ fertilization effect. Recent analysis of data from some of the longestrunning Free-Air $\mathrm{CO}_{2}$ Enrichment (FACE) sites, consisting of early-successional temperate ecosystems, found a $29.1 \pm$ $11.7 \%$ stimulation of biomass over a decade (Walker et al., 2019). A meta-analysis (Liu et al., 2019) of seven temperate FACE experiments combined with process-based modelling also found substantial sensitivity $\left(0.64 \pm 0.28 \mathrm{Pg} \mathrm{C} \mathrm{yr}^{-1}\right.$ per $100 \mathrm{ppm}$ ) of biomass accumulation to atmospheric $\mathrm{CO}_{2}$ increase, and the same study showed that ORCHIDEE model simulations were largely consistent with the experiments. However, other FACE experiments on mature temperate forests (Körner et al., 2005) and eucalyptus forests bring into question whether the fertilization effects observed in temperate FACE experiments can be extrapolated to other ecosystems. For example, the Swiss FACE study, a deciduous mature forest, found no significant biomass increase with enhanced $\mathrm{CO}_{2}$ (Körner et al., 2005), while a FACE experiment on a mature eucalyptus forest in Australia found that while $\mathrm{CO}_{2}$ stimulated an increase in $\mathrm{C}$ uptake through GPP, this did not carry to the ecosystem level, largely as a result of a concurrent increase in soil respiration (Jiang et al., 2020). Unfortunately, no results are yet available from any tropical FACE experiments, though the Amazon FACE experiment is underway and the eventual results will be crucial in developing our understanding of the $\mathrm{CO}_{2}$ fertilization effect beyond the temperate zone.

With these limitations in our understanding of tropical forest ecosystems in mind, over the entire simulation period (1861-2099) we estimate that aquatic $\mathrm{CO}_{2}$ evasion will increase by $79 \%$ and the export of $\mathrm{C}$ to the coast by $67 \%$. While there are no long-term observations of aquatic $\mathrm{CO}_{2}$ evasion in the Congo, a recent paper examined trends in observed DOC fluxes in the Congo at Brazzaville-Kinshasa over the last 30 years (N'kaya et al., 2020). The authors found a $45 \%$ increase in the annual flux of DOC from 11.1 $\mathrm{Tg} \mathrm{C} \mathrm{yr}^{-1}$ (mean from 1987-1993) to $16.1 \mathrm{TgC} \mathrm{yr}^{-1}$ (mean from 2006-2017). Comparing the same two periods, we find a smaller increase of $15 \%$ from 12.3 to

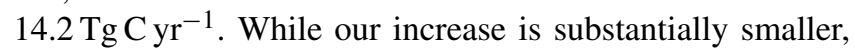
these observations are still over relatively short timescales, and thus interannual variations could have a considerable in- fluence over the means of the two periods. Irrespectively, it is encouraging that observations concur with the overall simulated increasing trend. Perhaps most interesting is that N'kaya et al. (2020) attribute this increase to hydrological changes, specifically an increase in flood events in the central basin (including the Cuvette Centrale). Over this period, we too attribute the increase in carbon fluxes to the coast in part to climate change (Fig. 11d), and over the full simulation period, the largest increase in $\mathrm{DOC}$ and $\mathrm{CO}_{2}$ leaching into the aquatic system occurs within the Cuvette Centrale (Fig. A1).

Comparing our results to models of other basins, our simulated increases in outgassing (79\%) and the export of $\mathrm{C}$ to the coast $(67 \%)$ are considerably greater than the $23 \%$ and $27 \%$ rises predicted for the Amazon Basin (Lauerwald et al., 2020) over the same period and under the same scenario. This is largely due to the fact climate change is predicted to have a substantial negative impact on the aquatic $\mathrm{C}$ fluxes in the Amazon, something that we do not find for the Congo where rainfall is projected to increase over the 21 st century (RCP6.0). In the Amazon, Lauerwald et al. (2020) show that while there are decadal fluctuations in precipitation and discharge, total values across the basin remain unchanged in 2099 compared to 1861 . However, changes in the spatial distribution of precipitation mean that the total water surface area actually decreases in the Amazon. Indeed, while we find an increase in the ratio of C exports to LOAC / NPP from $3 \%$ to $5 \%$, Lauerwald et al. (2020) find a comparative decrease.

Our simulated increase in DOC export to the coast up to the present day is smaller than findings recently published for the Mississippi River using the Dynamic Land Ecosystem Model (DLEM; Ren at al., 2016). In addition, the Mississippi study identified LUC including land management practices (e.g. irrigation and fertilization), followed by change in atmospheric $\mathrm{CO}_{2}$, as the biggest factors in the $40 \%$ increase in DOC export to the Gulf of Mexico (Ren et al., 2016). Another recent study (Tian et al., 2015) found an increase in DIC export from eastern North America to the Atlantic Ocean from 1901-2008 but no significant trend in DOC. The authors demonstrated that climate change and increasing atmospheric $\mathrm{CO}_{2}$ had a significant positive effect on long-term $\mathrm{C}$ export, while land use change had a substantial negative impact.

\subsection{Limitations and further model developments}

It is important to note that we can have greater confidence in the historic trend (until the present day), as future changes are more reliant on the skill of Earth system model predictions and of course on the accuracy of the RCP6.0 scenario. As discussed above, our understanding and representation of $\mathrm{CO}_{2}$ fertilization, especially in the tropics, is a major limitation. Moreover, the majority of land surface models, ORCHILEAK included in its current iteration, do not represent the effect of nutrient limitation on plant growth, meaning that 
estimates of land C uptake may be too large (Goll et al., 2017). There are also considerable uncertainties associated with future climate projections in the Congo Basin (Haensler et al., 2013). Nutrient limitation on growth and a better representation of the effects of enhanced $\mathrm{CO}_{2}$, particularly with regards to soil respiration (Jiang et al., 2020) and tree mortality (Hubau et al., 2020), are two crucial aspects which need to be further developed.

Additionally, we do not account for methane fluxes from Congo wetlands, estimated at 1.6 to $3.2 \mathrm{Tg}\left(\mathrm{CH}_{4}\right)$ per year (Tathy et al., 1992), and instead assume that all $\mathrm{C}$ is evaded in the form of $\mathrm{CO}_{2}$. Another limitation is the lack of accounting for bespoke peatland dynamics in the ORCHILEAK model. ORCHILEAK is able to represent the general reduction in $\mathrm{C}$ decomposition in water-logged soils, and indeed Hastie et al. (2019) demonstrated that increasing the maximum floodplain extent in the Amazon Basin led to an increase in NEP despite fuelling aquatic $\mathrm{CO}_{2}$ evasion because of the effect of reducing soil heterotrophic respiration. Furthermore, ORCHILEAK uses a "poor soils" mask forcing file (Fig. 2j) based on the Harmonized World Soil Database (FAO/IIASA/ISRIC/ISS-CAS/JRC, 2009), which prescribes reduced decomposition rates in low-nutrient and low-pH soils (e.g. Podzols and Arenosols). The effect of the "poor soils" forcing can clearly be seen in the spatial distribution of the soil $\mathrm{C}$ stock in Fig. A3, where the highest $\mathrm{C}$ storage coincides with the highest proportion of poor soils. Interestingly, this does not include the Cuvette Centrale wetlands (Fig. 1), an area which was recently identified as containing the world's largest intact tropical peatland and a stock of around $30 \mathrm{PgC}$ (Dargie at al., 2017). One potential improvement that could be made to ORCHILEAK would be the development of a new tailored "poor soils" forcing file for the Congo Basin which explicitly includes Histosols, perhaps informed by the Soil Grids database (Hengl et al., 2014), to better represent the Cuvette Centrale. This could, in turn, be validated and/or calibrated against the observations of Dargie et al. (2017). A more long-term aim could be the integration or coupling of the ORCHIDEE-PEAT module with ORCHILEAK. ORCHIDEE-PEAT (Qiu et al., 2019) represents peat as an independent sub-grid hydrological soil unit in which peatland soils are characterized by peat-specific hydrological properties and multi-layered transport of $\mathrm{C}$ and water. Thus far, it has only been applied to northern peatlands, and calibrating it to tropical peatlands, along with integrating it within ORCHILEAK, would require considerable further model development but would certainly be a valuable longer-term aspiration. This could also be applied across the tropical region and would allow us to comprehensively explore the implications of climate change and land use change for tropical peatlands. In addition, ORCHILEAK does not simulate the erosion and subsequent burial of POC within river and floodplain sediments. Although it does not represent the lateral transfer of POC, it does incorporate the decomposition of inundated litter as an important source of
DOC and dissolved $\mathrm{CO}_{2}$ to the aquatic system; i.e. it is assumed that POC from submerged litter decomposes locally in ORCHILEAK. Moreover, previous studies have found that DOC as opposed to POC (Spencer et al., 2016; Bouillon et al., 2012) overwhelmingly dominates the total load of $C$ in the Congo.

The representation of the rapid $\mathrm{C}$ loop of aquatic macrophytes should also be made a priority in terms of improving models such as ORCHILEAK, particularly in the tropics. As previously discussed, ORCHILEAK also fails to account for the weathering-derived flux $\left(\mathrm{HCO}_{3}^{-}\right)$. Finally, the issue of shifting cultivation demands further attention; at least for the present day a shifting cultivation forcing file could be developed based on remote sensing data (Tyukavina et al., 2018). For an additional discussion of the limitations of ORCHILEAK, please also see Lauerwald et al. (2017) and Hastie et al. (2019).

\section{Conclusions}

For the present day, we show that aquatic $\mathrm{C}$ fluxes, in particular $\mathrm{CO}_{2}$ evasion, are important components of the Congo Basin $\mathrm{C}$ balance that are larger than, for example, the combined fluxes from LUC and harvesting, with around $4 \%$ of terrestrial NPP being exported to the aquatic system each year. Our simulations show that these fluxes may have undergone considerable perturbation since 1861 to the present day and that under RCP6.0 this perturbation could continue; over the entire simulation period (1861-2099), we estimate that aquatic $\mathrm{CO}_{2}$ evasion will increase by $79 \%$ and the export of $\mathrm{C}$ to the coast by $67 \%$. We further find that the ratio of $\mathrm{C}$ exports to the LOAC / NPP could increase from $3 \%$ to $5 \%$, driven by both rising atmospheric $\mathrm{CO}_{2}$ concentrations and climate change. This calls for long-term monitoring of $\mathrm{C}$ levels and fluxes in the rivers of the Congo Basin and further investigation of the potential impacts of such change. Our results also highlight the limitations of the current generation of land surface models and call for investment in further model development. 
Appendix A

Table A1. Performance statistics for the modelled versus observed seasonality of discharge on the Congo at Brazzaville.

\begin{tabular}{lrrrc}
\hline Climate forcing & RMSE & NSE & $R^{2}$ & $\begin{array}{c}\text { Mean monthly } \\
\text { discharge } \\
\left(\mathrm{m}^{3} \mathrm{~s}^{-1}\right)\end{array}$ \\
\hline ISIMIP & $29 \%$ & 0.20 & 0.23 & 38944 \\
Princeton GPCC & $40 \%$ & -0.25 & 0.20 & 49784 \\
GSWP3 & $46 \%$ & -4.13 & 0.04 & 24880 \\
CRUNCEP & $65 \%$ & -15.94 & 0.01 & 16394 \\
Observed (HYBAM) & & & & 40080 \\
\hline
\end{tabular}

Table A2. Pearson correlation coefficient $(r)$ between detrended carbon fluxes and detrended climate variables.

\begin{tabular}{lrrrrrrr}
\hline & SHR & $\begin{array}{r}\text { Aquatic } \\
\mathrm{CO}_{2} \\
\text { evasion }\end{array}$ & Lateral C & NEP & Rain & Temp. & MEI \\
& & & & & & \\
\hline NPP & -0.48 & 0.68 & 0.72 & 0.90 & 0.64 & -0.57 & -0.09 \\
SHR & & -0.41 & -0.48 & -0.71 & -0.32 & 0.76 & 0.04 \\
Aquatic $\mathrm{CO}_{2}$ evasion & & & 0.92 & 0.41 & 0.87 & -0.30 & -0.21 \\
Lateral C & & & 0.52 & 0.81 & -0.38 & -0.15 \\
NEP & & & & 0.40 & -0.74 & -0.01 \\
Rain & & & & & -0.31 & -0.26 \\
Temp. & & & & & & 0.03 \\
\hline
\end{tabular}
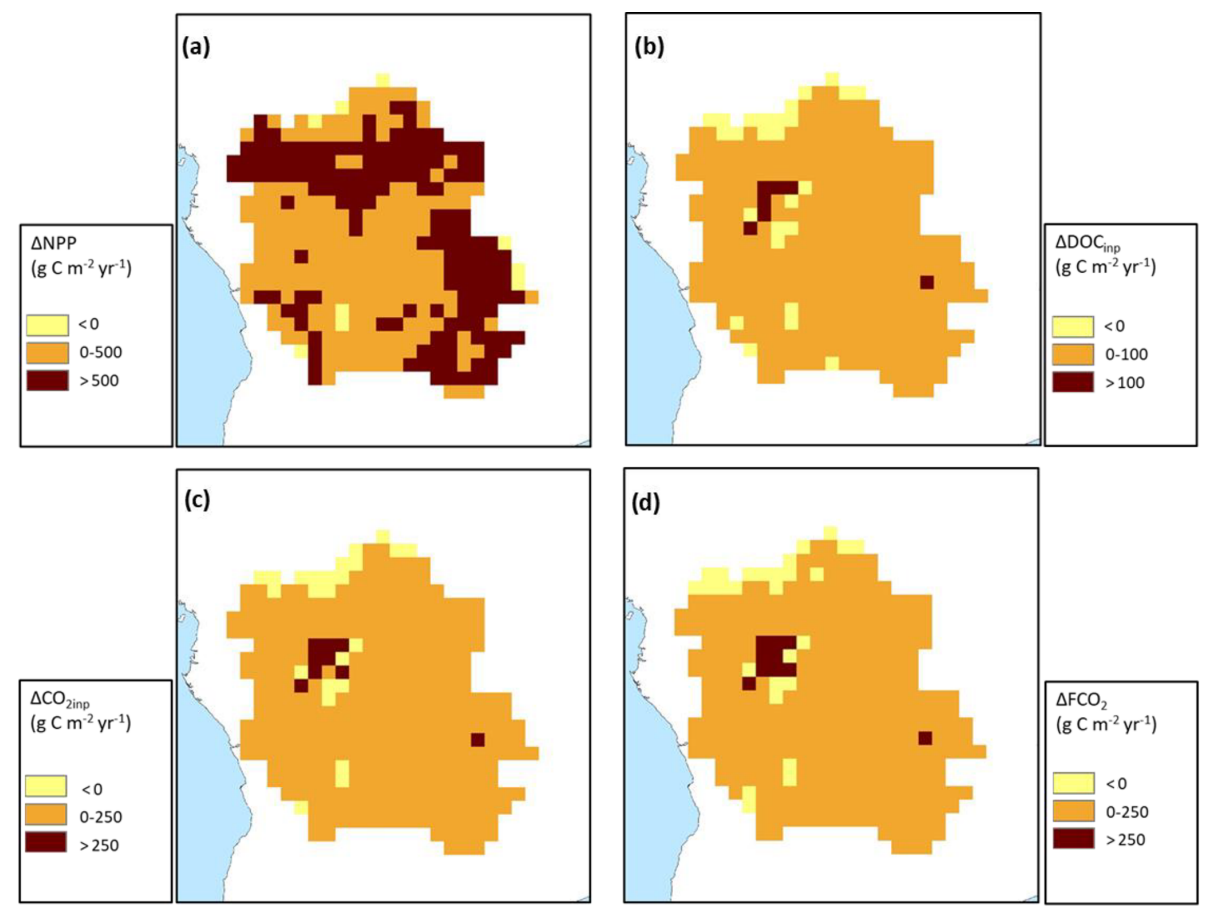

Figure A1. Change ( $\Delta, 2099$ minus 1861) in the spatial distribution of (a) terrestrial NPP, (b) DOC leaching into the aquatic system, (c) $\mathrm{CO}_{2}$ leaching into the aquatic system, and (d) aquatic $\mathrm{CO}_{2}$ evasion. All are at a resolution of $1^{\circ}$. 

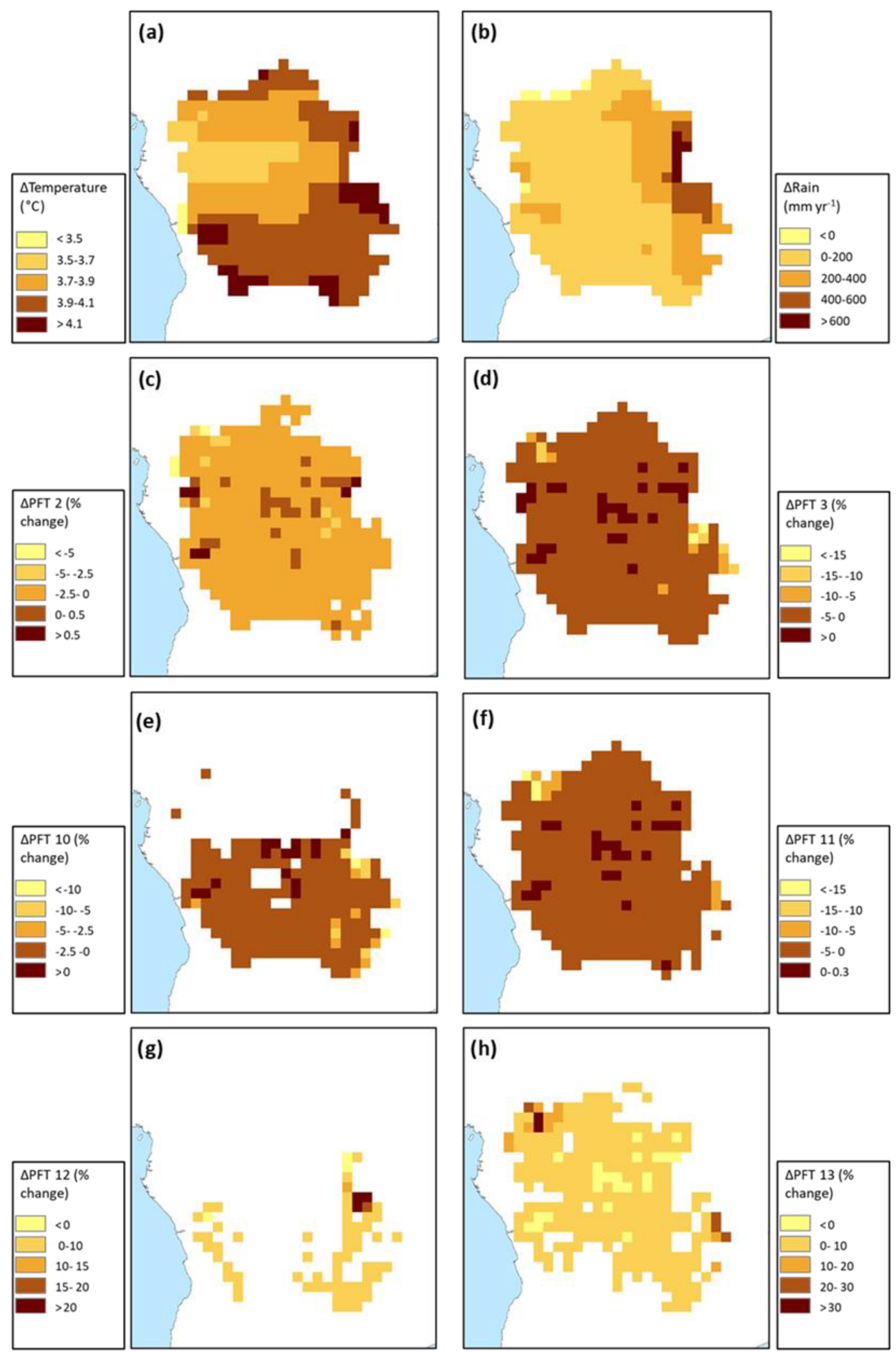

Figure A2. Change ( $\Delta, 2099$ minus 1861) in the spatial distribution of the principal climate and land use drivers across the Congo Basin; (a) mean annual temperature $\left({ }^{\circ} \mathrm{C}\right)$, (b) mean annual rainfall $\left(\mathrm{mm} \mathrm{yr}^{-1}\right)$, and $(\mathbf{c}-\mathbf{h})$ mean annual maximum vegetated fraction for PFTs 2,3 , $10,11,12$, and 13 . All are at a resolution of $1^{\circ}$. 


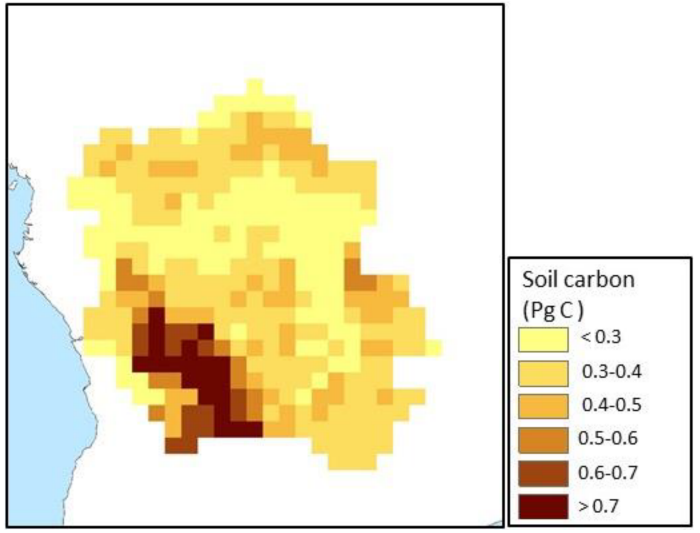

Figure A3. Spatial distribution of simulated total carbon stored in soils for the present day (1981-2020). 
Code availability. A description of the general ORCHIDEE code can be found here: http://forge.ipsl.jussieu.fr/orchidee/browser\# tags/ORCHIDEE_1_9_6/ORCHIDEE (last access: 1 July 2018) (ORCHIDEE, 2018a).

The main part of the ORCHIDEE code was written by Krinner et al. (2005). See d'Orgeval et al. (2008) for a general description of the river-routing scheme. For the updated soil C module, please see Camino-Serrano et al. (2018). For the source code of ORCHILEAK, see Lauerwald et al. (2017) https://doi.org/10.5194/gmd-10-3821-2017-supplement.

For details on how to install ORCHIDEE and its various branches, please see the user guide: http://forge.ipsl.jussieu.fr/ orchidee/wiki/Documentation/UserGuide (last access: 1 July 2018) (ORCHIDEE, 2018b).

Author contributions. AH, RL, PR, and PC all contributed to the conceptualization of the study. RL developed the model code, $\mathrm{AH}$ developed the novel forcing files for the Congo, and AH performed the simulations. FP provided the GIEMS dataset for model validation. AH prepared the paper with contributions from all coauthors. RL and PR provided supervision and guidance to $\mathrm{AH}$ throughout the research. PR acquired the primary financial support that supported this research.

Competing interests. The authors declare that they have no conflict of interest.

Acknowledgements. We would like to thank John Melack and the other anonymous reviewer for the time and effort they took to carefully review and improve the paper.

Financial support. Financial support was received from the European Union's Horizon 2020 research and innovation programme under Marie Skłodowska-Curie grant agreement no. 643052 (CCASCADES project). Pierre Regnier acknowledges funding from the European Union's Horizon 2020 research and innovation programme under grant agreement 776810 (project VERIFY). RL acknowledges funding from the ANR ISIPEDIA ERA4CS project and from French state aid managed by the ANR under the "Investissements d'avenir" programme with the reference ANR-16-CONV0003 .

Review statement. This paper was edited by Rui A. P. Perdigão and reviewed by John Melack and one anonymous referee.

\section{References}

Abril, G., Martinez, J.-M., Artigas, L. F., Moreira-Turcq, P., Benedetti, M. F., Vidal, L., Meziane, T., Kim, J.-H., Bernardes, M. C., Savoye, N., Deborde, J., Albéric, P., Souza, M. F. L., Souza, E. L., and Roland, F.: Amazon River carbon dioxide outgassing fuelled by wetlands, Nature, 505, 395-398, https://doi.org/10.1038/nature12797, 2014.

Allen, G. H. and Pavelsky, T. M.: Global extent of rivers and streams, Science, 361, 585-588, https://doi.org/10.1126/science.aat0636, 2018.

Becker, M., Papa, F., Frappart, F., Alsdorf, D., Calmant, S., Da Silva, J. S., Prigent, C., and Seyler, F.: Satellitebased estimates of surface water dynamics in the Congo River Basin, Int. J. Appl. Earth Obs. Geoinf., 66, 196-209, https://doi.org/10.1016/j.jag.2017.11.015, 2018.

Borges, A. V., Darchambeau, F., Teodoru, C. R., Marwick, T. R., Tamooh, F., Geeraert, N., Omengo, F. O., Guérin, F., Lambert, T., Morana, C., Okuku, E., and Bouillon, S.: Globally significant greenhouse-gas emissions from African inland waters, Nat. Geosci., 8, 637-642, https://doi.org/10.1038/ngeo2486, 2015 a.

Borges, A. V., Abril, G., Darchambeau, F., Teodoru, C. R., Deborde, J., Vidal, L. O., Lambert, T., and Bouillon, S.: Divergent biophysical controls of aquatic $\mathrm{CO}_{2}$ and $\mathrm{CH}_{4}$ in the World's two largest rivers, Scient. Rep., 5, 15614, https://doi.org/10.1038/srep15614, 2015 b.

Borges, A. V., Darchambeau, F., Lambert, T., Morana, C., Allen, G. H., Tambwe, E., Toengaho Sembaito, A., Mambo, T., Nlandu Wabakhangazi, J., Descy, J.-P., Teodoru, C. R., and Bouillon, S. Variations in dissolved greenhouse gases $\left(\mathrm{CO}_{2}\right.$, $\mathrm{CH}_{4}, \mathrm{~N}_{2} \mathrm{O}$ ) in the Congo River network overwhelmingly driven by fluvial-wetland connectivity, Biogeosciences, 16, 3801-3834, https://doi.org/10.5194/bg-16-3801-2019, 2019.

Bouillon, S., Yambélé, A., Spencer, R. G. M., Gillikin, D. P., Hernes, P. J., Six, J., Merckx, R., and Borges, A. V.: Organic matter sources, fluxes and greenhouse gas exchange in the Oubangui River (Congo River basin), Biogeosciences, 9, 2045-2062, https://doi.org/10.5194/bg-9-2045-2012, 2012.

Bouillon, S., Yambélé, A., Gillikin, D. P., Teodoru, C., Darchambeau, F., Lambert, T., and Borges, A. V.: Contrasting biogeochemical characteristics of the Oubangui River and tributaries (Congo River basin), Scient. Rep., 4, 5402, https://doi.org/10.1038/srep05402, 2014.

Bowring, S. P. K., Lauerwald, R., Guenet, B., Zhu, D., Guimberteau, M., Tootchi, A., Ducharne, A., and Ciais, P.: ORCHIDEE MICT-LEAK (r5459), a global model for the production, transport, and transformation of dissolved organic carbon from Arctic permafrost regions - Part 1: Rationale, model description, and simulation protocol, Geosci. Model Dev., 12, 3503-3521, https://doi.org/10.5194/gmd-12-3503-2019, 2019.

Bowring, S. P. K., Lauerwald, R., Guenet, B., Zhu, D., Guimberteau, M., Regnier, P., Tootchi, A., Ducharne, A., and Ciais, P.: ORCHIDEE MICT-LEAK (r5459), a global model for the production, transport, and transformation of dissolved organic carbon from Arctic permafrost regions - Part 2: Model evaluation over the Lena River basin, Geosci. Model Dev., 13, 507-520, https://doi.org/10.5194/gmd-13-507-2020, 2020.

Camino-Serrano, M., Guenet, B., Luyssaert, S., Ciais, P., Bastrikov, V., De Vos, B., Gielen, B., Gleixner, G., Jornet-Puig, 
A., Kaiser, K., Kothawala, D., Lauerwald, R., Peñuelas, J., Schrumpf, M., Vicca, S., Vuichard, N., Walmsley, D., and Janssens, I. A.: ORCHIDEE-SOM: modeling soil organic carbon (SOC) and dissolved organic carbon (DOC) dynamics along vertical soil profiles in Europe, Geosci. Model Dev., 11, 937957, https://doi.org/10.5194/gmd-11-937-2018, 2018.

CBFP - Congo Basin Forest Partnership: The forests of the Congo Basin - State of the Forest 2008, Publications Office of the European Union, Luxembourg, https://doi.org/10.2788/32259, 2009.

Ciais, P., Piao, S.-L., Cadule, P., Friedlingstein, P., and Chédin, A.: Variability and recent trends in the African terrestrial carbon balance, Biogeosciences, 6, 1935-1948, https://doi.org/10.5194/bg6-1935-2009, 2009.

Ciais, P., Yao, Y., Gasser, T., Baccini, A., Wang, Y., Lauerwald, R., Peng, S., Bastos, A., Li, W., Raymond, P. A., Canadell, J. G., Peters, G. P., Andres, R. J., Chang, J., Yue, C., Dolman, A. J., Haverd, V., Hartmann, J., Laruelle, G., Konings, A. J., King, A. W., Liu, Y., Luyssaert, S., Maignan, F., Patra, P. K., Peregon, A., Regnier, P., Pongratz, J., Poulter, B., Shvidenko, A., Valentini, R., Wang, R., Broquet, G., Yin, Y., Zscheischler, J., Guenet, B., Goll, D. S., Ballantyne, A. P., Yang, H., Qiu, C., and Zhu, D.: Empirical estimates of regional carbon budgets imply reduced global soil heterotrophic respiration, Nat. Sci. Rev., https://doi.org/10.1093/nsr/nwaa145, in press, 2020.

Cochonneau, G., Sondag, F., Guyot, J.-L., Geraldo, B., Filizola, N., Fraizy, P., Laraque, A., Magat, P., Martinez, J.-M., Nor iega, L., Oliveira, E., Ordonez, J., Pombosa, R., Seyler, F., Sidgwick, J., and Vauchel, P.: The environmental observation and research project, ORE HYBAM, and the rivers of the Amazon basin, in: Climate Variability and Change - Hydrological Impacts, IAHS Publ. 308, edited by: Demuth, S., Gustard, A., Planos, E., Scatena, F., and Servat, E., IAHS Press, UK, 44-50, 2006.

Cole, J. J., Prairie, Y. T., Caraco, N. F., McDowell, W. H., Tranvik, L. J., Striegl, R. G., Duarte, C. M., Kortelainen, P., Downing, J. A., Middleburg, J. J., and Melack, J.: Plumbing the Global Carbon Cycle: Integrating Inland Waters into the Terrestrial Carbon Budget, Ecosystems, 10, 172-185, https://doi.org/10.1007/s10021-006-9013-8, 2007.

Coynel, A., Seyler, P., Etcheber, H., Meybeck, M., and Orange, D.: Spatial and seasonal dynamics of total suspended sediment and organic carbon species in the Congo River, Global Biogeochem. Cy., 19, GB4019, https://doi.org/10.1029/2004GB002335, 2005.

Dargie, G. C., Lewis, S. L., Lawson, I. T., Mitchard, E. T. A., Page, S. E., Bocko, Y. E., and Ifo, S. A.: Age, extent and carbon storage of the central Congo Basin peatland complex, Nature, 542, 8690, https://doi.org/10.1038/nature21048, 2017.

De Kauwe, M. G., Keenan, T. F., Medlyn, B. E., Prentice, I. C., and Terrer, C.: Satellite based estimates underestimate the effect of $\mathrm{CO}_{2}$ fertilisation on net primary productivity, Nature Clim. Change, 6, 892-893, https://doi.org/10.1038/nclimate3105, 2016

d'Orgeval, T., Polcher, J., and de Rosnay, P.: Sensitivity of the West African hydrological cycle in ORCHIDEE to infiltration processes, Hydrol. Earth Syst. Sci., 12, 1387-1401, https://doi.org/10.5194/hess-12-1387-2008, 2008.

Drake, T. W., Raymond, P. A., and Spencer, R. G. M.: Terrestrial carbon inputs to inland waters: A current synthesis of es- timates and uncertainty, Limnol. Oceanogr. Lett., 3, 132-142, https://doi.org/10.1002/lol2.10055, 2018.

Fan, L., Wigneron, J.-P., Ciais, P., Chave, J., Brandt, M., Fensholt, R., Saatchi, S. S., Bastos, A., Al-Yaari, A., Hufkens, K., Qin, Y., Xiao, X., Chen, C., Myneni, R. B., Fernandez-Moran, R., Mialon, A., Rodriguez-Fernandez, N. J., Kerr, Y., Tian, F., and Penuelas, J.: Satellite-observed pantropical carbon dynamics, Nat. Plants, 5, 944-951, https://doi.org/10.1038/s41477-0190478-9, 2019.

FAO/IIASA/ISRIC/ISS-CAS/JRC: Harmonized World Soil Database (version 1.1), FAO, Rome, 2009.

Frieler, K., Lange, S., Piontek, F., Reyer, C. P. O., Schewe, J., Warszawski, L., Zhao, F., Chini, L., Denvil, S., Emanuel, K., Geiger, T., Halladay, K., Hurtt, G., Mengel, M., Murakami, D., Ostberg, S., Popp, A., Riva, R., Stevanovic, M., Suzuki, T., Volkholz, J., Burke, E., Ciais, P., Ebi, K., Eddy, T. D., Elliott, J., Galbraith, E., Gosling, S. N., Hattermann, F., Hickler, T., Hinkel, J., Hof, C., Huber, V., Jägermeyr, J., Krysanova, V., Marcé, R., Müller Schmied, H., Mouratiadou, I., Pierson, D., Tittensor, D. P., Vautard, R., van Vliet, M., Biber, M. F., Betts, R. A., Bodirsky, B. L., Deryng, D., Frolking, S., Jones, C. D., Lotze, H. K., LotzeCampen, H., Sahajpal, R., Thonicke, K., Tian, H., and Yamagata, Y.: Assessing the impacts of $1.5^{\circ} \mathrm{C}$ global warming - simulation protocol of the Inter-Sectoral Impact Model Intercomparison Project (ISIMIP2b), Geosci. Model Dev., 10, 4321-4345, https://doi.org/10.5194/gmd-10-4321-2017, 2017.

Goll, D. S., Vuichard, N., Maignan, F., Jornet-Puig, A., Sardans, J., Violette, A., Peng, S., Sun, Y., Kvakic, M., Guimberteau, M., Guenet, B., Zaehle, S., Penuelas, J., Janssens, I., and Ciais, P.: A representation of the phosphorus cycle for ORCHIDEE (revision 4520), Geosci. Model Dev., 10, 3745-3770, https://doi.org/10.5194/gmd-10-3745-2017, 2017.

Guimberteau, M., Drapeau, G., Ronchail, J., Sultan, B., Polcher, J., Martinez, J.-M., Prigent, C., Guyot, J.-L., Cochonneau, G., Espinoza, J. C., Filizola, N., Fraizy, P., Lavado, W., De Oliveira, E., Pombosa, R., Noriega, L., and Vauchel, P.: Discharge simulation in the sub-basins of the Amazon using ORCHIDEE forced by new datasets, Hydrol. Earth Syst. Sci., 16, 911-935, https://doi.org/10.5194/hess-16-911-2012, 2012.

Gumbricht, T., Roman-Cuesta, R. M., Verchot, L., Herold, M., Wittmann, F., Householder, E., Herold, N., and Murdiyarso, D.: An expert system model for mapping tropical wetlands and peatlands reveals South America as the largest contributor, Global Change Biol., 23, 3581-3599, https://doi.org/10.1111/gcb.13689, 2017.

Haensler, A., Saeed, F., and Jacob, D.: Assessment of projected climate change signals over central Africa based on a multitude of global and regional climate projections, in: Climate Change Scenarios for the Congo Basin, Report No. 11, edited by: Haensler, A., Jacob, D., Kabat, P., and Ludwig, F., Climate Service Centre Hamburg, Germany, ISSN 2192-4058, 2013.

Hartmann, J., Lauerwald, R., and Moosdorf, N.: A brief overview of the GLObal RIver CHemistry Database, GLORICH, Procedia Earth Planet. Sci., 10, 23-27, https://doi.org/10.1016/j.proeps.2014.08.005, 2014.

Hastie, A., Lauerwald, R., Ciais, P., and Regnier, P.: Aquatic carbon fluxes dampen the overall variation of net ecosystem productivity in the Amazon basin: An analysis of the interannual variability 
in the boundless carbon cycle, Global Change Biol., 25, 20942111, https://doi.org/10.1111/gcb.14620, 2019.

Heinimann, A., Mertz, O., Frolking, S., Egelund Christensen, A., Hurni, K., Sedano, F., Parsons Chini, L., Sahajpal, R., Hansen, M., Hurtt, G., and Poulter, B. (Eds.): A global view of shifting cultivation: Recent, current, and future extent, PLOS ONE, 12, e0184479, https://doi.org/10.1371/journal.pone.0184479, 2017.

Hengl, T., de Jesus, J. M., MacMillan, R. A., Batjes, N. H., Heuvelink, G. B. M., Ribeiro, E., Samuel-Rosa, A., Kempen, B., Leenaars, J. G. B., Walsh, M. G., and Gonzalez, M. R.: SoilGrids $1 \mathrm{~km}$ - Global Soil Information Based on Automated Mapping, PLOS ONE, 9, e105992, https://doi.org/10.1371/journal.pone.0105992, 2014.

Hubau, W., Lewis, S. L., Phillips, O. L., Affum-Baffoe, K., Beeckman, H., Cuní-Sanchez, A., Daniels, A. K., Ewango, C. E. N., Fauset, S., Mukinzi, J. M., Sheil, D., Sonké, B., Sullivan, M. J. P., Sunderland, T. C. H., Taedoumg, H., Thomas, S. C., White, L. J. T., Abernethy, K. A., Adu-Bredu, S., Amani, C. A., Baker, T. R., Banin, L. F., Baya, F., Begne, S. K., Bennett, A. C., Benedet, F., Bitariho, R., Bocko, Y. E., Boeckx, P., Boundja, P., Brienen, R. J. W., Brncic, T., Chezeaux, E., Chuyong, G. B., Clark, C. J., Collins, M., Comiskey, J. A., Coomes, D. A., Dargie, G. C., de Haulleville, T., Kamdem, M. N. D., Doucet, J. L., EsquivelMuelbert, A., Feldpausch, T. R., Fofanah, A., Foli, E. G., Gilpin, M., Gloor, E., Gonmadje, C., Gourlet-Fleury, S., Hall, J. S., Hamilton, A. C., Harris, D. J., Hart, T. B., Hockemba, M. B. N., Hladik, A., Ifo, S. A., Jeffery, K. J., Jucker, T., Yakusu, E. K., Kearsley, E., Kenfack, D., Koch, A., Leal, M. E., Levesley, A., Lindsell, J. A., Lisingo, J., Lopez-Gonzalez, G., Lovett, J. C., Makana, J. R., Malhi, Y., Marshall, A. R., Martin, J., Martin, E. H., Mbayu, F. M., Medjibe, V. P., Mihindou, V., Mitchard, E. T. A., Moore, S., Munishi, P. K. T., Bengone, N. N., Ojo, L., Ondo, F. E., Peh, K. S. H., Pickavance, G. C., Poulsen, A. D., Poulsen, J. R., Qie, L., Reitsma, J., Rovero, F., Swaine, M. D., Talbot, J., Taplin, J., Taylor, D. M., Thomas, D. W., Toirambe, B., Mukendi, J. T., Tuagben, D., Umunay, P. M., van der Heijden, G. M. F., Verbeeck, H., Vleminckx, J., Willcock, S., Wöll, H., Woods, J. T., and Zemagho, L.: Asynchronous carbon sink saturation in African and Amazonian tropical forests, Nature, 579, 80-87, https://doi.org/10.1038/s41586-020-2035-0, 2020.

Hurtt, G., Chini, L. P., Frolking, S., Betts, R., Feddema, J., Fischer, G., Fisk, J., Hibbard, K., Houghton, R., and Janetos, A.: Harmonization of land-use scenarios for the period 1500-2100: 600 years of global gridded annual land-use transitions, wood harvest, and resulting secondary lands, Climatic Change, 109, 117-161, https://doi.org/10.1007/s10584-011-0153-2, 2011.

Jiang, M., Medlyn, B., Drake, J., Duursma, R., Anderson, I., Barton, C., Boer, M., Carrillo, Y., Castandea-Gomez, L., Collins, L., Crous, K., De Kauwe, M., dos Santos, B., Emmerson, K., Facey, S., Gherlenda, A., Gimeno, T., Hasegawa, S., Johnson, S., Kännaste, A., Macdonald, C., Mahmud, K., Moore, B., Nazaries, L., Nielson, E., Nielsen, U., Niinemets, Ü., Jin Noh, N., Ochoa-Hueso, R., Pathare, V., Pendall, E., Pihlblad, J., Pineiro, J., Powell, J., Power, S., Reich, P., Renchon, A., Reigler, M., Rinnan, R., Rymer, P., Salomon, R., Singh, B., Smith, B., Tjoelker, M., Walker, J., Wujeska-Klause, A., Yang, J., Zaehle, S., and Ellsworth, D.: The fate of carbon in a mature forest under carbon dioxide enrichment, Nature, 580, 227-231, https://doi.org/10.1038/s41586-020-2128-9, 2020.
Kim, H.: Global Soil Wetness Project Phase 3 Atmospheric Boundary Conditions (Experiment 1) [Data set], Data Integration and Analysis System (DIAS), https://doi.org/10.20783/DIAS.501, 2017.

Körner, C., Asshoff, R., Bignucolo, O., Hättenschwiler, S., Keel, S. G., Pelaez-Riedl, S., Peppin, S., Siegwolf, R. T., and Zotz, G.: Carbon flux and growth in mature deciduous forest trees exposed to elevated $\mathrm{CO}_{2}$, Science, 309, 1360-1362, https://doi.org/10.1126/science.1113977, 2005.

Krinner, G., Viovy, N., de Noblet-Ducoudré, N., Ogée, J., Polcher, J., Friedlingstein, P., Ciais, P., Sitch, S., and Prentice, I. C.: A dynamic global vegetation model for studies of the coupled atmosphere-biosphere system, Global Biogeochem. Cy., 19, GB1015, https://doi.org/10.1029/2003GB002199, 2005.

Lange, S.: ISIMIP2b Bias-Correction Code, Zenodo, https://doi.org/10.5281/zenodo.1069050, 2017.

Lauerwald, R., Laruelle, G. G., Hartmann, J., Ciais, P., and Regnier, P. A. G.: Spatial patterns in $\mathrm{CO}_{2}$ evasion from the global river network, Global Biogeochem. Cy., 29, 534-554, https://doi.org/10.1002/2014GB004941, 2015.

Lauerwald, R., Regnier, P., Camino-Serrano, M., Guenet, B., Guimberteau, M., Ducharne, A., Polcher, J., and Ciais, P.: ORCHILEAK (revision 3875): a new model branch to simulate carbon transfers along the terrestrial-aquatic continuum of the Amazon basin, Geosci. Model Dev., 10, 3821-3859, https://doi.org/10.5194/gmd-10-3821-2017, 2017.

Lauerwald, R., Regnier, P., Guenet, B., Friedlingstein, P., and Ciais, P.: How Simulations of the Land Carbon Sink Are Biased by Ignoring Fluvial Carbon Transfers: A Case Study for the Amazon Basin, One Earth, 3, 226-236, https://doi.org/10.1016/j.oneear.2020.07.009, 2020.

Lehner, B. and Döll, P. Development and validation of a global database of lakes, reservoirs and wetlands, J. Hydrology, 296, 1-2, https://doi.org/10.1016/j.jhydrol.2004.03.028, 2004.

Lewis, S. L., Lopez-Gonzalez, G., Sonké, B., Affum-Baffoe, K., Baker, T. R., Ojo, L. O., Phillips, O. L., Reitsma, J. M., White, L., James, A., Comiskey, K., Djuikouo, M.-N., Ewango, C. E. N., Feldpausch, T. R., Hamilton, A. C., Gloor, M., Hart, T., Hladik, A., Lloyd, J., Lovett, J. C., Makana, J.-R., Malhi, Y., Mbago, F. M., Ndangalasi, H. J., Peacock, J., Peh, K. S.-H., Sheil, D., Sunderland, T., Swaine, M. D., Taplin, J., Taylor, D., Thomas, S. C., and Wöll, R. V. H.: Increasing carbon storage in intact African tropical forests, Nature, 457, 1003-1006, https://doi.org/10.1038/nature07771, 2009.

Liu, Y., Piao, S., Gasser, T., Ciais, P., Yang, H., Wang, H., Keenan, T. F., Huang, M., Wan, S., Song, J., Wang, K., Janssens, I. A., Peñuelas, J., Huntingford, C., Wang, X., Altaf Arain, M., Fang, Y., Fisher, J. B., Huang, M., Huntzinger, D. N., Ito, A., Jain, A. K., Mao, J., Michalak, A. M., Peng, C., Poulter, B., Schwalm, C., Shi, X., Tian, H., Wei, Y., Zeng, N., Zhu, Q., and Wang, T.: Field-experiment constraints on the enhancement of the terrestrial carbon sink by $\mathrm{CO}_{2}$ fertilization, Nat. Geosci., 12, 809-814, https://doi.org/10.1038/s41561-019-0436-1, 2019.

MacIntyre, S., Amaral, J. H. F., Barbosa, P. M., Cortés, A., Forsberg, B. R., and Melack, J. M.: Turbulence and gas transfer velocities in sheltered flooded forests of the Amazon Basin, Geophysical Res. Lett., 46, 9628-9636, https://doi.org/10.1029/2019GL083948, 2019. 
Masui, T., Matsumoto, K., Hijioka, Y., Kinoshita, T., Nozawa, T., Ishiwatari, S., Kato, E., Shukla, P. R., Yamagata, Y., and Kainuma, M.: An emission pathway to stabilize at $6 \mathrm{~W} / \mathrm{m}^{2}$ of radiative forcing, Climatic Change, 109, 59-76, https://doi.org/10.1007/s10584-011-0150-5, 2011.

Melack, J. M., Hess, L. L., Gastil, M., Forsberg, B. R., Hamilton, S. K., Lima, I. B., and Novo, E. M.: Regionalization of methane emissions in the Amazon Basin with microwave remote sensing, Global Change Biol., 10, 530-544, https://doi.org/10.1111/j.1365-2486.2004.00763.x, 2004.

Mitchell, D. S. and Rogers, K. H.: Seasonality/aseasonality of aquatic macrophytes in Southern Hemisphere inland water, in: Perspectives in Southern Hemisphere Limnology. Developments in Hydrobiology, vol. 28, edited by: Davies, B. R. and Walmsley, R. D., Springer, Dordrecht, 1985.

Nash, J. E. and Sutcliffe, J. V.: River flow forecasting through conceptual models: Part 1. A discussion of principles, J. Hydrol., 10, 282-290, 1970.

N'kaya, G. D. M., Orange, D., Bayonne Padou, S. M., Datok, P., and Laraque, A.: Temporal Variability of Sediments, Dissolved Solids and Dissolved Organic Matter Fluxes in the Congo River at Brazzaville/Kinshasa, Geosciences, 10, 341, https://doi.org/10.3390/geosciences10090341, 2020.

O'Loughlin, F., Trigg, M. A., Schumann, G. J.-P., and Bates, P. D.: Hydraulic characterization of the middle reach of the Congo River, Water Resour. Res., 49, 5059-5070, https://doi.org/10.1002/wrcr.20398, 2013.

ORCHIDEE: Source, available at: http://forge.ipsl.jussieu.fr/ orchidee/browser\#tags/ORCHIDEE_1_9_6/ORCHIDEE (last access: 1 July 2018), 2018a.

ORCHIDEE: User Guide to ORCHIDEE, available at: http://forge. ipsl.jussieu.fr/orchidee/wiki/Documentation/UserGuide (last access: 1 July 2018), 2018b.

Pan, S., Dangal, S. R. S., Tao, B., Yang, J., and Tian, H.: Recent patterns of terrestrial net primary production in Africa influenced by multiple environmental changes, Ecosyst. Health Sustainabil., 1, 1-15, https://doi.org/10.1890/EHS14-0027.1, 2015.

Papa, F., Prigent, C., Aires, F., Jimenez, C., Rossow, W. B., and Matthews, E.: Interannual variability of surface water extent at the global scale, 1993-2004, J. Geophys. Res., 115, D12111, https://doi.org/10.1029/2009JD012674, 2010.

Potapov, P. V., Turubanova, S. A., Hansen, M. C., Adusei, B., Broich, M., Altstatt, A., Mane, L., and Justice, C. O.: Quantifying forest cover loss in Democratic Republic of the Congo, 2000-2010, with Landsat ETM+ data, Remote Sens. Environ., 122, 106-116, https://doi.org/10.1016/j.rse.2011.08.027, 2012.

Prigent, C., Papa, F., Aires, F., Rossow, W. B., and Matthews, E. Global inundation dynamics inferred from multiple satellite observations, 1993-2000, J. Geophys. Res., 112, D12107, https://doi.org/10.1029/2006jd007847, 2007.

Qie, L., Telford, E. M., Massam, M. R., Tangki, H., Nilus, R., Hector, A., and Ewers, R. M.: Drought cuts back regeneration in logged tropical forests. Environ. Res. Lett., 14, 45012, https://doi.org/10.1088/1748-9326/ab0783, 2019.

Qiu, C., Zhu, D., Ciais, P., Guenet, B., Peng, S., Krinner, G., Tootchi, A., Ducharne, A., and Hastie, A.: Modelling northern peatland area and carbon dynamics since the Holocene with the ORCHIDEE-PEAT land surface model (SVN r5488), Geosci.
Model Dev., 12, 2961-2982, https://doi.org/10.5194/gmd-122961-2019, 2019.

Raymond, P. A., Hartmann, J., Lauerwald, R., Sobek, S., McDonald, C., Hoover, M., Butman, D., Striegl, R., Mayorga, E., Humborg, C., Kortelainen, P., Durr, H., Meybeck, M., Ciais, P., and Guth, P.: Global carbon dioxide emissions from inland waters, Nature, 503, 355-359, https://doi.org/10.1038/nature12760, 2013.

R Core Team: R: A language and environment for statistical computing, available at: http://www.r-project.org (last access: 27 December 2020), 2013.

Regnier, P., Friedlingstein, P., Ciais, P., Mackenzie, F. T., Gruber, N., Janssens, I. A., Laruelle, G. G., Lauerwald, R., Luyssaert, S., Andersson, A. J., Arndt, S., Arnosti, C., Borges, A. V, Dale, A. W., Gallego-Sala, A., Goddéris, Y., Goossens, N., Hartmann, J., Heinze, C., Ilyina, T., Joos, F., Larowe, D. E., Leifeld, J., Meysman, F. J. R., Munhoven, G., Raymond, P. A., Spahni, R., Suntharalingam, P., and Thullner, M.: Anthropogenic perturbation of the carbon fluxes from land to ocean, Nat. Geosci., 6, 597-607, https://doi.org/10.1038/ngeo1830, 2013.

Ren, W., Tian, H., Cai, W.-J., Lohrenz, S. E., Hopkinson, C. S., Huang, W.-J., Yang, J., Tao, B., Pan, S., and He, R.: Century long increasing trend and variability of dissolved organic carbon export from the Mississippi River basin driven by natural and anthropogenic forcing, Global Biogeochem. Cy., 30, 1288-1299, https://doi.org/10.1002/2016GB005395, 2016.

Richey, J. E., Melack, J. M., Aufdenkampe, A. K., Ballester, V. M., and Hess, L. L.: Outgassing from Amazonian rivers and wetlands as a large tropical source of atmospheric $\mathrm{CO}_{2}$, Nature, 416, 617620, https://doi.org/10.1038/416617a, 2002.

Sheffield, J., Goteti, G., and Wood, E. F.: Development of a 50Year High-Resolution Global Dataset of Meteorological Forcings for Land Surface Modeling, J. Climate, 19, 3088-3111, https://doi.org/10.1175/JCLI3790.1, 2006.

Silva, T. S. F., Costa, M. P. F., and Melack, J. M.: Annual net primary production of macrophytes in the eastern Amazon floodplain, Wetlands, 29, 747, https://doi.org/10.1672/08-107.1, 2009.

Smith, W. K., Fox, A. M., MacBean, N., Moore, D. J. P., and Parazoo, N. C.: Constraining estimates of terrestrial carbon uptake: new opportunities using long-term satellite observations and data assimilation, New Phytol., 225, 105-112, https://doi.org/10.1111/nph.16055, 2020.

Spencer, R. G. M., Hernes, P. J., Dinga, B., Wabakanghanzi, J. N., Drake, T. W., and Six, J.: Origins, seasonality, and fluxes of organic matter in the Congo River, Global Biogeochem. Cy., 30, 1105-1121, https://doi.org/10.1002/2016GB005427, 2016.

Tathy, J. P., Cros, B., Delmas, R. A., Marenco, A., Servant, J., and Labat, M.: Methane emission from flooded forest in central Africa, J. Geophys. Res., 97, 6159-6168, https://doi.org/10.1029/90JD02555, 1992.

Tian, H., Yang, Q., Najjar, R. G., Ren, W., Friedrichs, M. A. M., Hopkinson, C. S., and Pan, S.: Anthropogenic and climatic influences on carbon fluxes from eastern North America to the Atlantic Ocean: A process-based modeling study, J. Geophys. Res.Biogeo., 120, 752-772, https://doi.org/10.1002/2014JG002760, 2015.

Tranvik, L, J., Downing, J. A., Cotner, J. B., Loiselle, S. A., Striegl, R. G., Ballatore, T. J., Dillon, P., Finlay, K., Fortino, K., Knoll, L. B., Kortelainen, P. L., Kutser, T., Larsen, S., Laurion, I., 
Leech, D. M., McCallister, S. L., McKnight, D. M., Melack, J. M., Overholt, E., Porter, J. A., Prairie, Y., Renwick, W. H., Roland, F., Sherman, B. S., Schindler, D. W., Sobek, S., Tremblay, A., Vanni, M. J., Verschoor, A. M., von Wachenfeldt, E., and Weyhenmeyer, G. A.: Lakes and reservoirs as regulators of carbon cycling and climate, Limnol. Oceanogr., 54, 2298-2314, https://doi.org/10.4319/lo.2009.54.6_part_2.2298, 2009.

Tyukavina, A., Hansen, M. C., Potapov, P., Parker, D., Okpa, C., Stehman, S. V., Kommareddy, I., and Turubanova, S.: Congo Basin forest 485 loss dominated by increasing smallholder clearing, Sci. Adv., 4, 11, https://doi.org/10.1126/sciadv.aat2993, 2018.

Valentini, R., Arneth, A., Bombelli, A., Castaldi, S., Cazzolla Gatti, R., Chevallier, F., Ciais, P., Grieco, E., Hartmann, J., Henry, M., Houghton, R. A., Jung, M., Kutsch, W. L., Malhi, Y., Mayorga, E., Merbold, L., Murray-Tortarolo, G., Papale, D., Peylin, P., Poulter, B., Raymond, P. A., Santini, M., Sitch, S., Vaglio Laurin, G., van der Werf, G. R., Williams, C. A., and Scholes, R. J.: A full greenhouse gases budget of Africa: synthesis, uncertainties, and vulnerabilities, Biogeosciences, 11, 381-407, https://doi.org/10.5194/bg11-381-2014, 2014.

van Vuuren, D. P., Edmonds, J., Kainuma, M., Riahi, K., Thomson, A., Hibbard, K., Hurtt, G. C., Kram, T., Krey, V., Lamarque, J.-F., Masui, T., Meinshausen, M., Nakicenovic, N., Smith, S. J., and Rose, S. K.: The representative concentration pathways: an overview, Climatic Change, 109, 5-31, https://doi.org/10.1007/s10584-011-0148-z, 2011.

Verhegghen, A., Mayaux, P., de Wasseige, C., and Defourny, P.: Mapping Congo Basin vegetation types from $300 \mathrm{~m}$ and $1 \mathrm{~km}$ multi-sensor time series for carbon stocks and forest areas estimation, Biogeosciences, 9, 5061-5079, https://doi.org/10.5194/bg-9-5061-2012, 2012.

Viovy, N.: CRUNCEP Version 7 - Atmospheric Forcing Data for the Community Land Model, Research Data Archive at the National Center for Atmospheric Research, Computational and Information Systems Laboratory, available at: http://rda.ucar.edu/ datasets/ds314.3/ (last access: 27 December 2020), 2018.
Vörösmarty, C. J., Fekete, B. M., Meybeck, M., and Lammers, R. B.: Geomorphometric attributes of the global system of rivers at 30-minute spatial resolution, J. Hydrol., 237, 17-39, https://doi.org/10.1016/S0022-1694(00)00282-1, 2000.

Walker, A. P., De Kauwe, M. G., Medlyn, B. E., Zaehle, S., Iverson, C. M., Asao, S., Guenet, B., Harper, A., Hickler, T., Hungate, B. A., Jain, A. K., Luo, Y., Lu, X., Lu, M., Luus, K., Megonigal, J. P., Oren, R., Ryna, E., Shu, S., Talhelm, A., Wang, Y.-P., Warren, J. M., Werner, C., Xia, J., Yang, B., Zak, D. R., and Norby, R. J.: Decadal biomass increment in early secondary succession woody ecosystems is increased by $\mathrm{CO}_{2}$ enrichment, Nat. Commun., 10, 454, https://doi.org/10.1038/s41467-019-08348-1, 2019.

Wang, Z. A., Bienvenu, D. J., Mann, P. J., Hoering, K. A., Poulsen, J. R., Spencer, R. G. M., and Holmes, R. M.: Inorganic carbon speciation and fluxes in the Congo River, Geophys. Res. Lett., 40, 511-516, https://doi.org/10.1002/grl.50160, 2013.

Williams, C. A., Hanan, N. P., Neff, J. C., Scholes, R. J., Berry, J. A., Denning, A. S., and Baker, D. A.: Africa and the global carbon cycle, Carbon Balance Manage., 2, 3, https://doi.org/10.1186/1750-0680-2-3, 2007.

Yin, S., Li, X., and Wu, W.: Comparative analysis of NPP changes in global tropical forests from 2001 to 2013, IOP Conf. Ser.: Earth Environ. Sci., 57, 12009, https://doi.org/10.1088/17551315/57/1/012009, 2017.

Zhou, L., Tian, Y., Myneni, R. B., Ciais, P., Saatchi, S., Liu, Y. Y., Piao, S., Chen, H., Vermote, E. F., Song, C., and Hwang, T.: Widespread decline of Congo rainforest greenness in the past decade, Nature, 508, 86-90, https://doi.org/10.1038/nature13265, 2014.

Zhuravleva, I., Turubanova, S., Potapov, P., Hansen, M., Tyukavina, A., Minnemeyer, S., Laporte, N., Goetz, S., Verbelen, F., and Thies, C.: Satellite-based primary forest degradation assessment in the Democratic Republic of the Congo, 2000-2010, Environ. Res. Lett., 8, 24034, https://doi.org/10.1088/17489326/8/2/024034, 2013. 